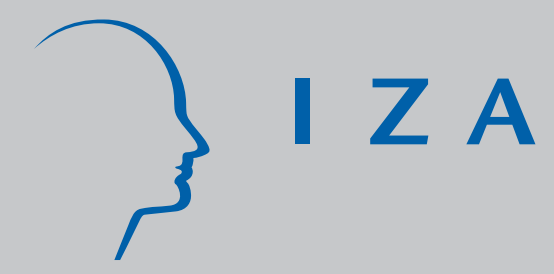

IZA DP No. 3711

Nepotism, Incentives and the Academic Success of College Students

Deniz Gevrek

Z. Eylem Gevrek

September 2008 


\title{
Nepotism, Incentives and the Academic Success of College Students
}

\author{
Deniz Gevrek \\ University of Southern Mississippi \\ and IZA
}

Z. Eylem Gevrek

University of Arizona

\section{Discussion Paper No. 3711 \\ September 2008 (updated October 2009)}

IZA

P.O. Box 7240

53072 Bonn

Germany

Phone: +49-228-3894-0

Fax: +49-228-3894-180

E-mail: iza@iza.org

Any opinions expressed here are those of the author(s) and not those of IZA. Research published in this series may include views on policy, but the institute itself takes no institutional policy positions.

The Institute for the Study of Labor (IZA) in Bonn is a local and virtual international research center and a place of communication between science, politics and business. IZA is an independent nonprofit organization supported by Deutsche Post World Net. The center is associated with the University of Bonn and offers a stimulating research environment through its international network, workshops and conferences, data service, project support, research visits and doctoral program. IZA engages in (i) original and internationally competitive research in all fields of labor economics, (ii) development of policy concepts, and (iii) dissemination of research results and concepts to the interested public.

IZA Discussion Papers often represent preliminary work and are circulated to encourage discussion. Citation of such a paper should account for its provisional character. A revised version may be available directly from the author. 
IZA Discussion Paper No. 3711

September 2008

\section{ABSTRACT \\ Nepotism, Incentives and the Academic Success of College Students}

This study investigates the role of self-employment statuses of parents on their children's college success and post-graduation plans by using a unique data set from a private university in Turkey. We assembled the data set by matching college students' administrative records with their responses to a survey we designed. Presence of self-employed parents has a strong negative effect on college success even after accounting for possible ability bias, intergenerational human capital transfers and various individual characteristics. The children of self-employed parents are also more likely to have entrepreneurial intent and are less likely to plan to attend graduate school.

JEL Classification: J24

Keywords: $\quad$ academic success, self-employment, post-graduation plans

Corresponding author:

Deniz Gevrek

University of Texas at Austin

1 University Station C3100

Austin, TX 78712

USA

E-mail: denizgevrek@yahoo.com

\footnotetext{
* We are very grateful to Daniel S. Hamermesh, Steve J. Trejo, Gerald S. Oettinger, Stephen G. Donald, Gönül Sengül and our sister G. Sevi Gevrek for their continued support and helpful discussions. We would also like to thank Ronald L. Oaxaca, Price V. Fishback, and the participants of seminars at the University of Texas at Austin and The University of Arizona for their helpful comments. Thanks to Michiel Johan Paus for the access to the administrative data; and Daniel S. Hamermesh, Anne Marie Jennings and Harsh Kalan for their editorial assistance.
} 


\section{Introduction}

Within the organization of a family, parental influence is central in molding a child's behavior. The occupational and educational choices of the parents may have far-reaching effects not only on their own lives but also on future generations. This study explores the role of self-employment statuses of parents on their children's college success and post-graduation plans. ${ }^{1}$

Previous studies indicate that college success, measured by GPA, is correlated with factors including individual and family characteristics, social background and individual discipline (e.g., Betts and Morell [1999]; Irandoust and Karlsson [2002]). None, however, considers self-employed parents and family businesses as factors affecting students' incentives to exert effort in college. Parental self-employment status and family business ownership may imply a larger set of post-graduation opportunities for a college student, but they may affect the incentives to obtain additional human capital during college.

According to human capital theory, additional years of education acquired by attending college add valuable skills to the stock of human capital and increase productivity. As per signalling theory (Spence [1973]), a college diploma may not add to individual productivity but has an informational value by signalling innate ability. Either theory can explain the choice of a high school senior who lacks the safety net of self-employed parents and a family business to go to college. Students with self-employed parents and family businesses may also choose to enroll in college to insure themselves against future uncertainty about the relative returns to different post-graduation plans. Therefore, regardless of the availability of a larger set of post-graduation employment options, a

\footnotetext{
${ }^{1}$ Our definition of self-employed parents excludes parents with professional occupations such as doctors, lawyers, accountants. We use "self-employed" and "non-professional self-employed" interchangeably.
} 
rational individual may choose to enroll in college.

When a job requires at least a college degree, years of schooling may lose their signalling and human capital values for the pool of college graduates. In this case, employers may focus on other information, such as GPA. ${ }^{2}$ College GPA may affect a student's probability of finding a job irrespective of signalling ability or acting as a proxy for human capital. Moreover, an extensive literature substantiates the impact of college GPA and college class rank on earnings (e.g., Weisbrod and Karpoff [1968], Wise [1975], Ehrenberg and Sherman [1987], James et al. [1989] and Hamermesh and Donald [2008]). While high college GPA may be important for a student planning on being a paid employee, a student who is planning on being self-employed, which may be affected by presence of self-employed parents, may not value college GPA as highly.

Intergenerational transfer of occupations, which is common in many countries, is well documented by previous literature. ${ }^{3}$ These intergenerational transfers are especially strong in self-employment: the children of self-employed parents are more likely to become self-employed (e.g., Lentz and Laband [1990], Dunn and Holtz-Eakin [2000] an Hout and Rosen [2000]). One of the widely cited reasons for intergenerational transfers is nepotism in the form of self-employed parents and family firms employing their children in their businesses or simply transferring the ownership of businesses. ${ }^{4}$ These intergenerational transfers also are possible if self-employed parents help their children to start a new business. Self-employed parents may provide non-monetary resources to their children, for

\footnotetext{
${ }^{2}$ For instance, in the USJOBS website, the federal government's official one-step source of jobs and employment information, applicants are asked to report their college GPAs.

${ }^{3}$ See Laband and Lentz $(1983 ; 1989 ; 1992)$ for evidence in the United States; Scoppa (2009) finds that nepotism may play an important role in intergenerational transfer of public sector jobs in Italy; Kramarz and Skans (2007) find evidence for intergenerational transfer of employers in Sweden.

${ }^{4}$ See Bertrand and Schoar (2006) for an extensive review on the role of families in family firms.
} 
instance by passing their work experience, managerial human capital, industry-specific knowledge, and career-specific human capital on to their children. ${ }^{5}$ Moreover, in the presence of capital market imperfections, successful entrepreneurs may relax the capital market constraints on their offspring by transferring their wealth (Dunn and Holtz-Eakin $[2000])$.

As a result, students with self-employed parents and family businesses may exert less effort in college if they anticipate secure jobs and earnings in their family businesses regardless of their college success. If, in turn, self-employed parents and family businesses employ relatives with lower levels of human capital, they may incur non-market costs and put themselves in a less competitive position compared to non-family businesses. Favoritism of this kind may affect the health and success of these businesses and of the economy.

Recent research on nepotism and firm performance shows that nepotism may be an important issue in the U.S. economy. Pérez-González (2006), using data from the CEO successions of publicly traded U.S. corporations, calculates that 36.4 percent of the these firms' CEO successions involved nepotism. The firms that promote related CEOs significantly underperform those that promote unrelated CEOs. ${ }^{6}$ Also, family CEOs who attended selective colleges perform better than CEOs who did not. ${ }^{7}$

We use a unique data set that we constructed by matching information from two

\footnotetext{
${ }^{5}$ Lentz and Laband (1990) distinguish between the general occupational skills acquired via college education and job-specific skills or managerial human capital acquired by experience. Lazear (2004) finds that among Stanford MBA alumni, the entrepreneurs study a more varied curriculum compared to those who work as employees.

${ }^{6}$ Bennedsen et al. (2007) find a negative impact of related CEOs on the performance of Danish firms.

${ }^{7} \mathrm{~A}$ high GPA may strongly predict future productivity as reflected in the performance of a business. The lower performance of related CEOs could stem from their lesser effort while in school, which previous studies have not controlled.
} 
different sources. The first part comes from a survey we initiated and conducted in December 2006. ${ }^{8}$ We surveyed students in the College of Economics and Administrative Sciences at a major private university in Turkey. The second part of the data set comes from the confidential administrative records of the university. While we are well aware of the possible uniqueness of the Turkish labor market, the same point could be made about any national market. Moreover, matching the survey data with students' administrative records would have been extremely difficult in the U.S. due to different privacy regulations.

This study investigates the impact of self-employment statuses of parents and postgraduation employment opportunities in shaping the incentives for college success. The empirical findings suggest that self-employed parents and family businesses have a strong negative effect on college students' GPAs, after controlling for demographic characteristics, ability, college major, and parental education. GPAs of men with two self-employed parents or only a self-employed mother are the lowest, even after controlling for ability bias. The impact of self-employed parents on women's GPAs is similar to that of on men's GPAs only when the only self-employed parent is the father.

We also find that the children of self-employed parents are more likely to have entrepreneurial post-graduation plans. The impact of having only a self-employed father on future self-employment plans is large, while the impact of having two self-employed parents on entrepreneurial intent is even larger. Students with self-employed parents are not only more likely to plan to be entrepreneurs, but they are less likely to plan to attend to graduate school.

\footnotetext{
${ }^{8}$ See survey questionnaire in Appendix C.
} 


\section{Theoretical Model}

The objective of this theoretical framework is to understand how the presence of selfemployed parents may affect students' future career and effort choices while in college.

We use a partial equilibrium model to study systematically the effects of self-employed parents on students' college GPAs. Let us assume an individual lives only for two periods, goes to school in the first period and works in the second. In the first period she simultaneously makes her post-graduation career choice and determines how much time to spend in college (attending classes and studying), $e$, while enjoying the remainder of her finite time in leisure activities, $l=T-e$, where $T$ is total time available. Utility in the first period is only a function of leisure.

In the second period, with probability $(1-p)$ the student will work as a paid employee. In this case, she supplies her labor inelastically and earns $y(e)$, where $e$ is the time/effort she spent in school. ${ }^{9}$ She consumes all her income, and her second period utility depends only on consumption.

With probability $p$, she gets the option to become self-employed. In this case she can choose between self-employment (SE) or paid employment (PE). In either case she inelastically supplies her labor in the second period. The difference between these careers is the income they generate. If she chooses paid employment, she earns $y(e)$. If she chooses self-employment, she earns a stochastic income, $y_{S E}$, which is independent of $e .^{10}$

Let $\tilde{u}$ and $u$ be the utility functions in the first and the second periods. They are twice continuously differentiable, $\widetilde{u} \in C^{2}$ and $u \in C^{2}$, increasing and concave, $\widetilde{u}^{\prime}>0, u^{\prime}>0$, $\widetilde{u}^{\prime \prime}<0$, and $u^{\prime \prime}<0$. Because their arguments are in different units (time vs. income),

\footnotetext{
${ }^{9} y(e)$ satisfies the following conditions: $y(e) \in C^{2} ; y(e)^{\prime}>0$; and $y(e)^{\prime \prime}<0$.

${ }^{10}$ This simplifying independence assumption is made to keep the model tractable.
} 
they may or may not have different forms.

At the beginning of the first period, after observing individual-specific $p$, the student simultaneously makes leisure/effort and post-graduation career choices to maximize her lifetime utility. We can formally state her utility maximization problem as:

$$
\begin{array}{r}
\max _{\{e, l\}} \widetilde{u}(l)+\beta\left[p \max \left\{E u\left(y_{S E}\right) ; u(y(e))\right\}+(1-p) u(y(e))\right] \\
\text { s.t. } e+l \leq T
\end{array}
$$

If she chooses paid employment, then the optimal effort choice $e_{P E}^{*}$ will satisfy the following first-order condition:

$$
-\widetilde{u}^{\prime}\left(T-e_{P E}^{*}\right)+\beta u^{\prime}\left(y\left(e_{P E}^{*}\right)\right) y^{\prime}\left(e_{P E}^{*}\right)=0
$$

If she chooses self-employment, then let $e_{S E}^{*}$ be her optimal effort choice, which will satisfy the first-order condition:

$$
-\widetilde{u}^{\prime}\left(T-e_{S E}^{*}\right)+\beta(1-p) u^{\prime}\left(y\left(e_{S E}^{*}\right)\right) y^{\prime}\left(e_{S E}^{*}\right)=0
$$

Equation (3) implies that the optimal effort will depend on $p$ if an individual chooses self-employment. Comparing two otherwise identical students, the one with self-employed parent(s) is more likely to get the self-employment option. In other words, she is expected to have a higher $p$. A higher likelihood of getting the self-employment option for those with self-employed parents may be caused by sheer nepotism and/or intergenerational transfers 
of entrepreneurial human capital and ability, among other things. It is straightforward to show that the higher the probability of getting the self-employment option, the lower the optimal effort when an individual chooses self-employment, $\frac{d e_{S E}^{*}}{d p}<0 .{ }^{11}$

Equations (2) and (3) together imply that the optimal effort is always smaller if a student chooses self-employment. ${ }^{12}$

$$
e_{S E}^{*}<e_{P E}^{*} \quad \text { for } \quad p \in(0,1) \text {. }
$$

Given a chance to choose between two options, a student chooses self-employment over paid employment if the expected utility from self-employment is greater than or equal to the utility from paid employment, $E u\left(y_{S E}\right) \geq u(y(e))$. The likelihood of choosing selfemployment is increasing in the expected utility from self-employment, which depends on the distribution of the self-employment income. Self-employed parents may increase the expected utility, $E u\left(y_{S E}\right)$, by providing monetary and non-monetary resources to their children. For instance, the presence of self-employed parents may reduce the riskiness (in the sense of second-order stochastic dominance) of the self-employment option. ${ }^{13}$ In this case, comparing two otherwise identical students, the child of self-employed parent(s) will have a larger expected utility from self-employment and therefore is more likely to choose

\footnotetext{
${ }^{11}$ Let $F=-\widetilde{u}^{\prime}\left(T-e_{S E}^{*}\right)+\beta(1-p) u^{\prime}\left(y\left(e_{S E}^{*}\right)\right) y^{\prime}\left(e_{S E}^{*}\right)=0$. Therefore, $\frac{d e_{S E}^{*}}{d p}=-\frac{\partial F / \partial p}{\partial F / \partial e_{S E}^{*}}$. Taking the partial derivatives, we get $\frac{d e_{S E}^{*}}{d p}=-\frac{-\beta u^{\prime}\left(y\left(e_{S E}^{*}\right)\right) y^{\prime}\left(e_{S E}^{*}\right)}{\widetilde{u}^{\prime \prime}\left(T-e_{S E}^{*}\right)+\beta(1-p)\left(u^{\prime \prime}\left(y\left(e_{S E}^{*}\right)\right)\left(y^{\prime}\left(e_{S E}^{*}\right)\right)^{2}+u^{\prime}\left(y\left(e_{S E}^{*}\right)\right) y^{\prime \prime}\left(e_{S E}^{*}\right)\right)}<0$.

${ }^{12}$ Proof: Let us assume that $e_{S E}^{*} \geq e_{P E}^{*}$ and rearranging the first order conditions (equations (2) and (3)), we get $\frac{\widetilde{u}^{\prime}\left(T-e_{S E}^{*}\right)}{(1-p) u^{\prime}\left(y\left(e_{S E}^{*}\right)\right) y^{\prime}\left(e_{S E}^{*}\right)}=\frac{\widetilde{u}^{\prime}\left(T-e_{P E}^{*}\right)}{u^{\prime}\left(y\left(e_{P E}^{*}\right)\right) y^{\prime}\left(e_{P E}^{*}\right)}$. Given $p \in(0,1)$, we must have $\frac{\widetilde{u}^{\prime}\left(T-e_{S E}^{*}\right)}{u^{\prime}\left(y\left(e_{S E}^{*}\right)\right) y^{\prime}\left(e_{S E}^{*}\right)}<$ $\frac{\widetilde{u}^{\prime}\left(T-e_{P E}^{*}\right)}{u^{\prime}\left(y\left(e_{P E}^{*}\right)\right) y^{\prime}\left(e_{P E}^{*}\right)}$. If $e_{S E}^{*} \geq e_{P E}^{*}$, then we have $\widetilde{u}^{\prime}\left(T-e_{S E}^{*}\right) \geq \widetilde{u}^{\prime}\left(T-e_{P E}^{*}\right)$, and $u^{\prime}\left(y\left(e_{S E}^{*}\right)\right) y^{\prime}\left(e_{S E}^{*}\right) \leq$ $u^{\prime}\left(y\left(e_{P E}^{*}\right)\right) y^{\prime}\left(e_{P E}^{*}\right)$, which implies $\frac{\widetilde{u}^{\prime}\left(T-e_{S E}^{*}\right)}{u^{\prime}\left(y\left(e_{S E}^{*}\right)\right) y^{\prime}\left(e_{S E}^{*}\right)} \geq \frac{\widetilde{u}^{\prime}\left(T-e_{P E}^{*}\right)}{u^{\prime}\left(y\left(e_{P E}^{*}\right) y^{\prime}\left(e_{P E}^{*}\right)\right.}$. Proof by contradiction.

${ }^{13}$ This conclusion is based on the fact that if a random variable $\mathrm{Y}$ is riskier than $\mathrm{X}$, i.e. the distribution of $\mathrm{X}$ second-order stochastically dominates that of $\mathrm{Y}$, and if $\mathrm{X}$ and $\mathrm{Y}$ have the same mean, then $E[u(X)] \geq$ $E[u(Y)]$ for all concave functions $\mathrm{u}($.$) .$
} 
self-employment.

The model provides two empirically testable hypotheses. First, the offspring of selfemployed parents are more likely to choose the self-employment option. Second, students with self-employed parents will on average have lower GPAs, because their optimal effort is lower.

\section{A New Data Set}

The empirical analysis in this study relies on two data sources. The first part comes from an in-class survey we designed and administered to students in the College of Economics and Administrative Sciences of a private university in Turkey. ${ }^{14}$ The survey was conducted in December 2006, spanning a period of three weeks. In order to improve the survey, we pre-tested it on a group of 20 students from another college in the same university. The students of the College of Economics and Administrative Sciences answered detailed questions about their personal and family characteristics, GPA, scholarship status, post-graduation plans, number of younger and older siblings, and family business characteristics, if applicable.

The second part of the data set comes from the administrative records of all sophomore, junior and senior students in the College. ${ }^{15}$ The administrative data contain detailed information on each student's GPA, gender, age, year in college, Turkish Central University Entrance Exam score or Student Selection Examination (SSE) score, major, scholarship status, and parental education levels and occupations. We are able to match the surveyed

\footnotetext{
${ }^{14}$ The College of Economics and Managerial Sciences offers the following majors: Economics, Economics (Honors), Business Administration, Business Administration-Economics, Business Administration-Economics (Honors), Government, International Relations and International Finance.

${ }^{15}$ Freshmen are excluded from the sample since their GPAs were not reported by December 2006.
} 
individuals with their administrative records.

Of the 1,122 sophomores, juniors and seniors in the College of Economics and Administrative Sciences, we obtained responses from 499 (44.5 percent). The non-surveyed sample consists of students who failed to attend class on the day of the survey. The probability of surveying a student may depend on a student's course load along with other determinants of attendance, such as the weather and idiosyncratic shocks. Therefore, students with heavier course loads are expected to be more likely to appear in our surveyed sample, because they are more likely to be present in a greater number of classes than those with lighter loads. The item non-response rate among the surveyed students was very low, since we monitored students closely and insisted that they respond to as many questions as possible.

Summary statistics for the entire sample of students $(n=1,122)$, surveyed students $(\mathrm{n}=499)$ and non-surveyed students $(\mathrm{n}=623)$ are presented in Table 1 . The first row shows that the surveyed students have higher-than-average cumulative GPAs on a fourpoint scale. Consistent with expectations, the surveyed students take more classes (6.12 per semester) compared to others (5.88 per semester). The surveyed students are slightly younger, and there are many more female students among the respondents. The surveyed students, on average, have higher SSE scores. The educational attainment of the parents is similar for surveyed and non-surveyed students. The average educational attainment of mothers is 11.55 years, while that of fathers is 13.37 years. Seventy-four percent of mothers are either housewives, unemployed or retired. This percentage is consistent with the 25.5 percent labor force participation rate reported by the State Institute of Statistics based on the 2000 Turkish Household Labor Force Survey.

The distributions of parental occupations for the entire sample suggest that almost 
44 percent of the fathers and 6 percent of the mothers are non-professional self-employed individuals. Our definition of the self-employed parent category does not include professionals such as doctors, lawyers, consultants, and accountants, among others. Therefore, our definition of "self-employed" corresponds to "non-professional self-employed." In the interest of saving space, we occasionally use "self-employed" instead of "non-professional self-employed." Tansel (2001) calculates more recent figures for occupational distributions classified by urban and rural residence, based on the 2000 Turkish Household Labor Force Survey. Self-employed men make up 27 and 50 percent of the urban and rural labor forces respectively, while self-employed women make up 5 and 14 percent respectively. The occupational distributions of the parents in our sample are thus similar to those of men and women in Turkey, based on the calculations from Census and Household Survey data sets.

U.S. self-employment rates are somewhat different from the ones in our sample. For instance, Fairlie (1999) calculates that the U.S. self-employment rate for whites is 15.23 percent. Hout and Rosen (2000), report a 24.2 percent self-employment rate for fathers, while Dunn and Holtz-Eakin (2000) find that the overall propensities for self-employment for fathers and mothers are 30 percent and 9 percent, respectively.

Having a self-employed parent does not necessarily imply that the family owns a business. A family business requires having employees other than self-employed parents. Of 191 surveyed students who have self-employed fathers, however, only four reported that their father is the only worker in the business. The rest of these 191 students reported that their family businesses employed anywhere from two to 1,000 people. Out of these 191 students, 103 of their self-employed parents do not employ non-family members at 
the management level. ${ }^{16}$

Table 1 shows the distribution of post-graduation plans of the surveyed students. Sixteen percent of the students plan to work in their family businesses, and four percent are planning to start a new business. We consider these two groups of students as "firstdegree entrepreneurs." Seven and seventeen percent of the students said that their postgraduation plans involve either "working as employees first, and then working for their family businesses," or "working as employees first, and then starting a new business," respectively. We regard these two groups of students as "second-degree entrepreneurs." Twenty percent of the surveyed students said that they are planning to work as employees. Thirty-three percent said that they are planning to go to graduate school, and three percent said that they have other plans.

Table 2 shows the mother-father matched parental occupation distributions for the entire sample and the surveyed sample. The upper panel of Table 2 shows that out of 1,122 students, 499 have non-professional self-employed fathers, while only 64 have non-professional self-employed mothers. Forty-six students reported having two nonprofessional self-employed parents. The lower panel shows that out of 499 surveyed students, 191 and 28 have non-professional self-employed fathers and mothers, respectively.

\section{A. The Turkish Educational System}

In Turkey the only gateway to enter college is by taking the Student Selection Exam (SSE). ${ }^{17}$ The SSE score is well accepted as a good proxy for a student's ability. The

\footnotetext{
${ }^{16}$ Students with two self-employed parents and those with only self-employed mothers reported similar family business structures and self-employment patterns to those with only self-employed fathers.

${ }^{17}$ The Turkish Student Placement Center states that the SSE has two objectives: a) To assure a
} 
Organisation for Economic Co-operation and Development (OECD) (2008), states that SSE measures the basic aptitude of students for university-level study similarly to the traditional Scholastic Aptitude Test (SAT) of the College Board in the U.S. To quote OECD (2008):18 "Neither the ÖSS, nor the SAT intends to measure what students know about specific subject matter learned from secondary education. In fact, in contrast to the subject-related tests that existed before 1999, success on the current ÖSS is not necessarily related to a student's mastery of a specific subject area in such as mathematics, natural sciences or the social sciences." Because the students observed in our sample took the SSE after 2001, we are fairly confident about using the SSE score as a measure of ability.

The SSE is conducted every year in mid-June. ${ }^{19}$ In 2006 1,570,357 students took the test. Public universities had 163,844 spots, while private universities had 24,045 spots. Only 156,120 students enrolled in public universities and 16,111 enrolled in private universities. In Turkey, public and private universities differ, especially in tuition and other fees. Public university tuition costs for the academic year 2006-2007 varied between $\$ 82$ and $\$ 682$, while this private university's tuition is approximately $\$ 10,600$ per year. ${ }^{20}$

\section{Impact of Self-Employed Parents on College Success}

In this section we test the hypothesis that students with self-employed parents are

balance between the demand for higher education and the number of spots available in higher education institutions; and b) To select and place students with the highest probability of success in appropriate higher education programs by considering their preferences and performance on the SSE.

${ }^{18}$ ÖSS is the Turkish acronym for Öğrenci Seçme Sınavı, which is translated in English as Student Selection Exam(SSE).

${ }^{19}$ See the detailed information on the SSE at this link: "http://www.osym.gov.tr/BelgeGoster.aspx? F6E10F8892433CFF7A2395174CFB32E15F640FC6104C033D"

${ }^{20}$ The average tuition for private universities is approximately $\$ 10,000$. 
expected to have lower GPAs on average. The empirical model is given by:

$$
G P A_{i}=X_{i}^{\prime} \delta_{0}+\delta_{1} S E_{\text {father only }}+\delta_{2} S E_{\text {mother only }}+\delta_{3} S E_{\text {both parents }}+\epsilon_{i}
$$

where $i$ indexes students. The dependent variable is the cumulative college GPA as of November 2006. College GPA is measured out of a maximum of 4 points. The indicator variables, $S E_{\text {father only }}, S E_{\text {mother only }}$ and $S E_{\text {both parents }}$, equal one if only the father or only the mother or both parents are non-professional self-employed individuals. ${ }^{21}$ In order to see if self-employed parents have differential effects on their sons' and daughters' GPAs, equation (5) is estimated for the samples of men and women separately.

The explanatory variable set in equation (5) contains $X_{i}$, which is the vector of individual and parental characteristics, and $\epsilon_{i}$, the error term. If parents of students with low GPAs took the unlikely path of becoming self-employed to secure the future of their offspring, then the indicator variables for parental self-employment, $S E_{\text {father only }}$, $S E_{\text {mother only }}, S E_{\text {both parents }}$ are potentially endogenous to the GPA equation. In this case, the coefficient estimates of these variables are biased and inconsistent. We believe that reverse causality of this kind is highly unlikely, because parents generally make their occupational choices far before their children are enrolled in college.

Unobserved ability bias arises if the occupational choices of parents and parental ability, which is expected to be highly correlated with the offspring's ability, are correlated. More specifically, if high-ability parents are less likely to be self-employed, the negative coefficients for the presence of self-employed parents are downward biased, and vice-versa. We tackle this issue by including two proxy variables for unobserved ability, the SSE scores

\footnotetext{
${ }^{21}$ The omitted group is the students with no non-professional self-employed parent.
} 
of students and variables measuring parental education levels.

Table 3 shows the results of estimating equation (5) for two alternative specifications in three samples. The basic specification includes age, hours studied, and family income, in addition to the indicators for non-professional self-employed parents. ${ }^{22}$ The extended specification augments the basic specification with the SSE score (a proxy for ability), indicator variables for the year of enrollment (or test year), SSE score and test year interactions, seven indicator variables for college major, and two continuous variables for parental education levels. ${ }^{23}$

Column 1 of Table 3 reports the estimates for the basic specification in the pooled sample of men and women. The students with only a self-employed father earned on average 0.23 point lower GPAs. The impact of having only a self-employed mother on GPA is -0.18 , yet not significant at conventional levels. Interestingly, students with two self-employed parents earned on average 0.37 point lower GPAs than those of students with no self-employed parents. The impact of having self-employed parents on GPAs is not trivial. For instance, in standard deviation units, having only a self-employed father or two self-employed parents is associated with $0.35 \sigma$ and $0.58 \sigma$ lower GPAs, respectively.

Columns 2 and 3 show that in the basic specification the self-employment statuses of parents do not differentially affect men's and women's college GPAs, with one exception. While the impact of having only a self-employed mother is not statistically significant in the pooled or women's samples, for men having only a self-employed mother is associated with on average 0.35 point lower GPAs than those with no self-employed parents. This

\footnotetext{
${ }^{22}$ Data on family income and number of hours spent studying are available for surveyed students only. We include two indicator variables for the missing responses of the non-surveyed students.

${ }^{23}$ The year of college enrollment corresponds to the SSE year because in Turkey the SSE scores are only valid for one year. The results are not affected if we include eight indicator variables for parental education instead of two continuous variables.
} 
negative and significant effect on men may be due to the possibility that men are more likely to emulate their mother if the only self-employed parent is the mother. This may be true if there are differences in the intergenerational transfer of self-employment based on the gender of self-employed parent and the gender of child.

Columns 4-6 present the results for the extended specification. The coefficient estimates of $S E_{\text {father only }}, S E_{\text {mother only }}$, and $S E_{\text {both parents }}$ are smaller in absolute value (-0.09, -0.01 and -0.24 , respectively) but the estimates of $S E_{\text {father only }}$ and $S E_{\text {both parents }}$ are still highly significant in the pooled sample. ${ }^{24}$ The overall impact of having only a selfemployed father on GPA is driven equally by men and women. Both groups earned on average $0.09($ s.e. $=0.04)$ point lower GPAs compared to those with no self-employed parents. Interestingly, the presence of only a self-employed mother or two self-employed parents has a differential impact on the GPAs of men and women. Men who have only a self-employed mother or two self-employed parents earned 0.26 (s.e.=0.09) and 0.32 (s.e.=0.09) points lower GPAs respectively. For women, the effects of having only a selfemployed mother or two self-employed parents on GPAs, reported in column 6 of Table 3, are insignificant 0.07 (s.e. $=0.14$ ) and -0.13 (s.e. $=0.12)$, respectively.

Smaller negative coefficients of the variables measuring parental self-employment status suggest that if we fail to control for individual and parental ability, the coefficient estimates for the variables accounting for parental self-employment are downward biased. Unsurprisingly, the ability proxy, SSE score has a positive and significant effect on students' GPAs. ${ }^{25}$ These downward-biased estimates imply a negative correlation between

\footnotetext{
${ }^{24}$ The first specification provides an upper bound to the causal effect of parental self-employment on college GPA. The main idea of adding more controls to the basic specification is to tighten the upper bound for the estimates.

${ }^{25}$ For the year 2002, the coefficient estimate for the SSE score is highly significant at 0.012. For the years 2003, 2004, and 2005, the impact of SSE score on a student's college GPA is also positive yet
} 
parental ability and self-employment, because students' ability measured by SSE scores correlates positively with college GPA and there are intergenerational transfers in ability.

Columns 4-6 reveal that father's education does not have a statistically significant effect on GPA. On the other hand, mother's education has a negative impact on GPA in the men's sub-sample. If highly educated mothers are less likely to be stay-at-home mothers, the negative impact of highly educated mothers may be due to less time devoted to child development.

The F-test shows that the indicator variables for parental self-employment are jointly significant in the GPA equation for all specifications; i.e. $H_{0}: S E_{\text {father only }}=S E_{\text {mother only }}=$ $S E_{\text {both parents }}=0$ is rejected, except for the extended specification in the women's sample.

The OLS results suggest that the children of the self-employed have, on average, lower GPAs even after controlling for ability bias. ${ }^{26}$ If we assume that they would follow their parents' self-employment by either working for their family businesses or starting new businesses, these students may have had fewer incentives to exert high effort even in high school. This lack of incentive would then be reflected in their SSE scores. To examine this issue, we test whether the SSE scores differ systematically between the offspring of self-employed parents and other parents for various parental self-employment structures. The null hypothesis is that the difference between the average SSE scores of students weaker.

${ }^{26}$ The lower GPAs of the children of the self-employed may result from students exerting lower effort in college, which can be measured by the number of hours spent studying, attending classes etc. While a detailed time use diary would be ideal to measure the effort in college, we use 413 (of 1,122) students' responses to our survey question, "On average how many hours a day do you study?" as a proxy for effort in college. The estimates of the effect of self-employed parents on the number of hours studied is presented in Table B1 of Appendix B. While we find a negative statistically significant effect of selfemployed parents on the number of hours studied only for men with only a self-employed mother, the number of hours studied, which is only available for 413 students, is not a perfect proxy for the effort in college. 
with or without self-employed parents is not statistically different from zero. ${ }^{27}$ If the null hypothesis is rejected, the SSE scores of students with self-employed parents differ from those of other students and selection may be an important issue. Table 4 shows that even though students with self-employed parents have slightly lower SSE scores, in each case we fail to reject the equality of the average test scores between the students with and without self-employed parents. ${ }^{28}$

So far we have considered linear regression-based methods in which the identification of the "treatment" (the presence of non-professional self-employed parents) on college GPA depends on the linear selection on observables. To examine the robustness of our results we also use matching methods. Although both matching methods and regressionbased methods estimate the impact of a "treatment" under the assumption of selection on observables, Black and Smith (2004) discuss two potential problems associated with the use of linear regression methods in observational studies. First, the linear conditioning on the observables may create bias due to misspecification of the functional form in a linear regression-based model. Second, the linearity assumption may mask the failure of the "common support" issue. The details on the matching algorithms used and propensity score matching estimates appear in Appendix A. We find that our results are robust to consideration of matching methods instead of linear regression-based models.

\section{A. Isolating the Effect of Parents with Professional Occupations}

We next investigate whether having a parent with a professional occupation affects

\footnotetext{
${ }^{27}$ The groups are students with only self-employed fathers, only self-employed mothers, and two selfemployed parents. We exclude any professional self-employed parents.

${ }^{28} \mathrm{We}$ also included the SSE score and parental self-employment interactions in our regressions. The coefficients of these interaction terms are not statistically significant.
} 
GPA. The data set allows us to differentiate between parents who are retired, unemployed/out of the labor force, employees, non-professional self-employed individuals and professionals. ${ }^{29}$ The professionals may be self-employed (those who have their own private practices), employees (those who work, for instance, in a hospital or a law firm), or both self-employed and employees at the same time.

The treatment group in equation (5) includes students with two non-professional selfemployed parents $\left(S E_{\text {both parents }}\right)$, students with only a non-professional self-employed mother $\left(S E_{\text {mother only }}\right)$, and with only a non-professional self-employed father $\left(S E_{\text {father only }}\right)$, while in the last two cases the other parent can be retired, unemployed/out of the labor force, employee or professional. ${ }^{30}$ The comparison group (i.e. students with no $S E_{\text {both parents }}, S E_{\text {mother only }}$ or $S E_{\text {father only }}$ ) includes students who have: (i) two parents with professional occupations; (ii) only a mother with a professional occupation and a father who is either retired, unemployed/out of the labor force or an employee; (iii) only a father with a professional occupation and a mother who is either retired, unemployed/out of the labor force or an employee; and (iv) two parents who are any combination of retired, unemployed/out of the labor force or employee. ${ }^{31}$ If having a professionally employed parent correlates with GPA, the presence of professionally employed parents in the treatment and the comparison groups may bias the estimates in Table 3.

In order to separate the impact of having a non-professional self-employed parent from that of having a professionally employed parent, we recoded the parental occupation

\footnotetext{
${ }^{29}$ The self-employed group excludes professional self-employed parents. Professional self-employed parents are, for instance, doctors, lawyers, and accountants.

${ }^{30}$ Eleven of those 1,122 students who have non-professional self-employed fathers have professionally employed mothers, while five of those 1,122 students who have non-professional self-employed mothers have professionally employed fathers.

${ }^{31}$ There are 34, 26, 181 and 414 students in groups (i)-(iv) respectively, a total of 655 students in the comparison group.
} 
groups so that mother/father can either be non-professional self-employed, professional, or other (retired, unemployed/out of the labor force, or an employee). This recoding gives nine mutually exclusive, parental-matched occupational groups.

Table 5 shows the estimates for when we repeat the estimation exercise of Table 3 by including five more indicator variables for parental occupation (the comparison group now consists of 414 students who do not have any non-professional self-employed or professional parents) in the pooled sample. The coefficients of $S E_{\text {father only }}, S E_{\text {mother only }}$ and $S E_{\text {both parents }}$ are unaffected when we include these five indicator variables. The extended specification of Table 5 indicates that the coefficients of $S E_{\text {father }} \wedge$ Promother $_{\text {, }}$ $S E_{\text {mother }} \wedge$ Profather, Pro father only, Pro ${ }_{\text {mother only }}$ and Proboth parents are not statistically significant at any conventional levels. ${ }^{32}$ Our results are robust when we isolate the effect of the professionally employed parents from that of the non-professional self-employed parents.

\section{Parental Occupation and Post-Graduation Plans}

In this section, we quantify whether different parental employment statuses generate different post-graduation plans. To address this issue, the surveyed students were asked to choose one of the following seven post-graduation plans: 1) work in the family business; 2) start a new business; 3) work as an employee; 4) first work as an employee and then work for the family business; 5) first work as an employee and then start a new business 6) go to graduate school; or 7) other.

\footnotetext{
${ }^{32}$ Interestingly, for students who have a non-professional self-employed mother(father) and a professionally employed father(mother), i.e., $S E_{\text {mother }} \wedge$ Profather $\left(S E_{\text {father }} \wedge\right.$ Pro $\left._{\text {mother }}\right)$, the non-professional self-employed parent does not have a significant negative effect, partly due to very small sample sizes: there are 11 and 5 out of 1,122 students with $S E_{\text {father }} \wedge$ Promother $_{\text {mon }} S E_{\text {mother }} \wedge$ Profather respectively.
} 


\section{A. Determinants of Post-Graduation Plans}

The model and the previous literature suggest that, if entrepreneurial tendencies are passed on from parent to child, the children of self-employed people are more likely to be self-employed after graduation. Equations for different post-graduation plans of a student $i$ can be written as:

$$
P G P_{j i}=1\left[Z_{i}^{\prime} \alpha_{j 0}+\alpha_{j 1} S E P_{j i}^{\prime}+\epsilon_{j i}>0\right] \quad j=1, \ldots, 6,
$$

where $P G P_{j i}$ for $j=1, \ldots, 6$ are indicator variables for six post-graduation plan categories excluding "planning to be an employee." $S E P_{j i}$ is a vector of explanatory variables for different parental self-employment statuses. $Z_{i}$ is a vector of additional exogenous variables that would affect post-graduation plans. These variables are age, SSE score, indicator variables for gender, year of enrollment, and interaction terms for SSE score and year of enrollment. Equation (6) can be estimated as a multinomial logit model.

Table 6 shows the marginal effects evaluated at the sample means relative to the base outcome "planning to be an employee." The $S E P_{j i}$ includes two indicator variables: $S E_{\text {father only }}$ and $S E_{\text {both parents }} .{ }^{33}$ Students with only a self-employed father are 26 percentage points more likely to plan to work in their family businesses than to plan to be employees. Strikingly, students with two self-employed parents are almost 62 percentage points more likely to plan to work in their family businesses. Students with only a selfemployed father are 7 percentage points more likely to plan to be employees first and then

\footnotetext{
${ }^{33}$ These indicator variables take on a value one if only the father or both parents are non-professional self-employed individuals. We cannot control for $S E_{\text {mother only }}$ since some of the dependent variables (post-graduation plans) do not vary with the variable $S E_{\text {mother only }}$, the indicator variable for having only a self-employed mother. For the same reason, we cannot include the $\left(F \times S E_{\text {father only }}\right)$ or $(F \times$ $S E_{\text {both parents }}$ ) interaction terms.
} 
become self-employed after graduation.

Having self-employed parents not only increases the likelihood of a college student's entrepreneurial intent, but also it decreases a student's probability of planning to invest further in education. Having two self-employed parents decreases the probability of planning to go to graduate school by 37 percentage points, while having only a self-employed father decreases the probability of planning to go to graduate school by 10 percentage points. Women are less likely plan to work in the family business or start a new business than to become employees. A rise in family income increases the probability of planning to work in the family business.

In Table 6 , the $\chi^{2}$-tests reveal that $S E_{\text {father only }}$ and $S E_{\text {both parents }}$ are jointly significant at the one percent level. However, the choice-specific (outcome-specific) $\chi^{2}$-tests show that these two variables are not jointly significant in the equation for planning to go to graduate school and planning to pursue other future plans. ${ }^{34}$ To test the validity of using a multinomial logit model, we use Hausman-McFadden's IIA test. The results in Table 6 show the IIA assumption is valid and that a multinomial logit model is appropriate.

\section{B. Survey Non-Response Bias}

A potential problem with the above estimates, which focus on the surveyed sample only, arises from the possibility of survey non-response bias, a special type of sampleselection problem. The distributions of parental occupations in Table 1 and Table 2 show that students with self-employed fathers are under-represented in the survey. ${ }^{35}$ The dependent variable in our multinomial logit model, post-graduation plans, is only available

\footnotetext{
${ }^{34}$ Refer to Table 6.

${ }^{35}$ Thirty-eight percent of the surveyed students have self-employed fathers, while 50 percent of the non-surveyed students have self-employed fathers.
} 
for the surveyed sample. Table 1 demonstrates that the surveyed and the non-surveyed students are not identical along many other dimensions. Therefore, estimation results based only on the surveyed sample may suffer from a survey non-response bias.

In order to account for this possible bias we estimate the following two-equation binary response model with selection:

$$
\begin{aligned}
& S_{i 1}=1\left[Z_{i 1}^{\prime} \delta_{1}+\epsilon_{i 1}>0\right]-\text { surveyed. } \\
& E_{i 2}=1\left[Z_{i 2}^{\prime} \delta_{2}+\epsilon_{i 2}>0\right]-\text { plan to be } 1^{\text {st }}-\text { degree entrepreneur. }
\end{aligned}
$$

We can estimate this two-equation model via a maximum likelihood procedure by making two assumptions: ( $i$ ) The latent errors, $\epsilon_{i 1}$ and $\epsilon_{i 2}$, are bivariate normally distributed with zero means, unit variances and a correlation coefficient of $\rho_{1}$; and $(i i)$ these latent errors are independent of $Z_{i 1}{ }^{36}$ Equation (8) is the structural equation of interest, where $E_{i 2}$ is a binary indicator that takes on a value of one if student $i$ plans to be a firstdegree entrepreneur after graduation. Equation (7) is the selection equation, where $S_{i 1}$ is the survey response indicator and $E_{i 2}$ is observed only when $S_{i 1}=1$. The explanatory variable set in equation (8) contains $Z_{i 2}$, which is a vector of exogenous variables that would affect post-graduation plans, such as parental self-employment, gender, gender and parental self-employment interactions, age, SSE score, year of enrollment, and interaction terms for SSE score and year of enrollment.

To identify possible survey non-response bias, we need at least one explanatory variable in $Z_{i 1}$ of equation (7) in addition to the $Z_{i 2}$ of the structural equation. Otherwise, the identification is from the nonlinearities in the probit equations. A potential identifier

\footnotetext{
${ }^{36}$ See Wooldridge (2002) for details on this model.
} 
should be correlated with whether a student is surveyed or not, but it should not affect post-graduation plans directly. As mentioned in the data section, the probability of responding to our in-class survey is expected to be higher for students who attend many classes. Therefore, the students who take a heavier course load are more likely to appear in our in-class survey.

We use individual current course load to identify survey response. However, students who have entrepreneurial tendencies may consistently take fewer or more classes compared to those lacking entrepreneurial intentions. In this case, using current course load to identify the survey response equation without accounting for a student's average course load may be problematic. To solve this problem, we also control for a student's average course load both in the selection equation and in the structural equation. Even if a future entrepreneur takes fewer classes each semester, accounting for the individual average course loads, the current course load should not directly affect future plans. Moreover, as Table 1 shows, current course load is clearly correlated with the probability of being surveyed.

Whether a variable is a valid instrument is always open to debate. Nevertheless, we see no reason to assume that the course load taken by a student at the beginning of the Fall 2006 semester, controlling for their average course load over their college career, should affect a student's post-graduation plans (recorded in December 2006). An instrument is strong if its coefficient is highly significant in the survey response equation. Staiger and Stock (1997) suggest that if the t-statistic for an instrument is above $\sqrt{10}$, it is considered to be a strong instrument. If $\rho_{1} \neq 0$, students are non-randomly assigned to the surveyed sample, and the standard probit estimation of the impact of self-employed parents on entrepreneurial intent without correcting for survey non-response bias will yield biased 
and inconsistent estimates.

The estimation strategy can be summarized as follows: We estimate the selection equation via probit and get $\widehat{\delta_{1}}$ in order to construct the conditional densities, $P\left(E_{i 2}=1\right.$ | $\left.Z_{1 i}, S_{1 i}=1\right)$ and $P\left(E_{i 2}=0 \mid Z_{1 i}, S_{1 i}=1\right)$. Then we estimate $\widehat{\delta_{2}}$ and $\widehat{\rho_{1}}$ via a maximum likelihood model using $P\left(E_{i 2}=1 \mid Z_{1 i}, S_{1 i}=1\right), P\left(E_{i 2}=0 \mid Z_{1 i}, S_{1 i}=1\right)$ and $\widehat{\delta_{1}}$.

Table 7 shows the results of estimating the two-equation model described above for two alternative specifications. The first has an indicator variable $\left(1 \leq S E_{\text {Parent }}\right)$ that takes on a value of one if at least one parent is self-employed, while the second has two indicator variables, $S E_{\text {father only }}$ and $S E_{\text {both parents }}$, to control for self-employed parents. The first and fourth columns of Table 7 present the coefficients from the probit selection equation (7). Students with at least one self-employed parent or only a self-employed father are less likely to be in the surveyed sample. In the second specification, the $\chi^{2}$-test reveals that the variables $S E_{\text {father only }}$ and $S E_{\text {both parents }}$ and their interactions with the female indicator variable are jointly significant in both the selection and structural equations. We find that women are more likely to be in the surveyed sample. Consistent with our expectations, the coefficient of the identifier variable, current course load, is positive and highly significant in all specifications (with t-values larger than $\sqrt{10}$ ). Interestingly, students with heavier average course loads are less likely to be surveyed.

The second and fifth columns show the marginal effects after estimating (8) as a probit model without accounting for survey non-response bias. Having at least one selfemployed parent, only a self-employed father or two self-employed parents increases the probability of planning to be a first-degree entrepreneur by 26, 27 and 59 percentage points, respectively. The impact of having two self-employed parents is the largest on students planning to be first-degree entrepreneurs. For students with only a self-employed 
father or two self-employed parents, the self-employment statuses of the parents do not differentially affect children's entrepreneurial intent by gender. Older students and women are less likely to plan on becoming entrepreneurs.

The last columns of models 1 and 2 show the marginal effects after estimating the second stage of the two-equation model. The coefficients of $\left(1 \leq S E_{\text {Parent }}\right)$ and $S E_{\text {father only }}$ are highly significant and much larger than those predicted from the models that do not control for the survey non-response bias, while the coefficient on $S E_{\text {both parents }}$ is not affected. The probability of first-degree entrepreneurial intent increases by 35, 35 and 59 percentage points for the students with $\left(1 \leq S E_{\text {Parent }}\right), S E_{\text {father only }}$ and $S E_{\text {both parents }}$, respectively. This increase is over and above the probability of the baseline outcome, which is 20 percent. $^{37}$ The negative impact of age and being female on planning to be a first-degree entrepreneur disappear when we correct for the survey non-response bias.

The Wald test statistics for the independence of latent errors, $\left(H_{0}: \rho_{1}=0\right)$, of the selection and the structural equations are insignificant for both models. Therefore, the Wald tests of independent equations fail to reject the null hypotheses. ${ }^{38}$ This result indicates that ignoring selection into the surveyed sample would not render the estimates of the probit model for $E_{i 2}$ equation biased and inconsistent, yet some of the estimates do change after we account for survey non-response bias.

\section{Conclusions}

This study provides evidence that parental self-employment and family businesses significantly affect students' college GPAs. Our results suggest that GPAs of men with

\footnotetext{
${ }^{37}$ See Table 1.

${ }^{38}$ The correlation coefficients in Model 1 and Model 2 are insignificant.
} 
two non-professional self-employed parents or with only a non-professional self-employed mother are the lowest. We find that parental self-employment has a differential impact on men's and women's GPAs with one exception: having only a non-professional selfemployed father has a similar effect on the GPAs of both men and women. For women, the impact of non-professional self-employed parents on their GPAs is not as strong: selfemployment statuses of parents have a negative statistically significant effect on their GPAs only for those with only a non-professional self-employed father. The inclusion of various controls reduces the negative impact on GPA of having only a self-employed father by about half, while the negative impact on GPA of having two self-employed parents is reduced by only one-third. We test the robustness of our results by applying propensity score matching methods. The matching estimates are similar to those estimates that are calculated using regression-based models.

An explanation for the lower GPAs of the children of self-employed parents is that in the presence of self-employed parents and family businesses students have a larger set of post-graduation options and are more likely to plan on becoming self-employed due to intergenerational transfer of self-employment. Hence, these students may not exert as much effort in acquiring the task-specific career-oriented human capital taught in college. When family businesses opt for employing their children with lower levels of human capital instead of following a competitive hiring procedure, family businesses deviate from profitmaximizing behavior and internalize possible costs this may impose on their businesses. Nepotism of this kind prevails very frequently in most countries and threatens the success of family businesses and of economies.

The results also confirm that students with family businesses are more likely to have entrepreneurial tendencies upon graduation. Children of the self-employed are much 
more likely to planning on joining their respective family businesses after graduation. After accounting for survey non-response bias, the probability of having the strongest entrepreneurial intent among students with at least one self-employed parent is almost 175 percent more than the baseline case. More interestingly, for students with two selfemployed parents, this probability is almost 300 percent more than the baseline case. Children of self-employed parents are not only more likely to become self-employed upon graduation, but they are also less likely to plan to attend graduate school.

Future research might investigate the role of sibling order and the number and gender of siblings on post-graduation plans and college success. Preliminary results based on this data set show that the presence and number of older male and female siblings interact with the self-employment status of the parents to affect students' college success and post-graduation plans. For instance, while having only older sister(s) increases the college success of students with no self-employed parents, having only older sister(s) reduces college success of those with self-employed parents. Interestingly, having only older brother(s) has no statistically significant effect on college GPAs of students without selfemployed parents, while having only older brother(s) raises the college GPAs of students with self-employed parents.

Although cumulative college GPA serves as a good measure of college success, future work might utilize the panel data on GPAs and consider the standard deviation of a student's college GPA to measure consistency in reaching and sustaining target GPAs. Another line of research would involve studying the dynamic behavior of college students throughout college that accounts for changes in GPA.

Future studies may involve understanding the relative importance of nepotism, intergenerational transfers of entrepreneurial ability, and level of access to managerial and 
industry-specific human capital in generating these effects. The limitations of the data set in the current study do not permit these analyses. 


\section{References}

Becker, Sascha O., and Andrea Ichino. Estimation of average treatment effects based on propensity scores. The Stata Journal 2002; 2; 4:358-377.

Bennedsen, M., Kasper M. Nielsen, Francisco Pérez-González, and Daniel Wolfenzon. Inside the Family Firm: The Role of Families in Succession Decisions and Performance. Quarterly Journal of Economics 2007; 122; 2:647-91.

Bertrand, Marianne, and Antoinette Schoar. The Role of Family in Family Firms. The Journal of Economic Perspectives 2006; 20; 2:73-96.

Betts, Julian R., and Darlene Morell. The Determinants of Undergraduate Grade Point Average: The Relative Importance of Family Background, High School Resources, and Peer Group Effects. Journal of Human Resources 1999; 34; 2:268-93.

Black, Dan A., and Jeffrey A. Smith. How Robust is the Evidence on the Effects of the College Quality? Evidence from Matching. Journal of Econometrics 2004; 121; 1-2:99-124

Caliendo, Marco, and Sabine Kopeinig. Some Practical Guidance for the Implementation of Propensity Score Matching. Journal of Economic Surveys 2008; 22; 1:31-72.

Cochran, William G., and Donald B. Rubin. Controlling Bias in Observational Studies: A Review. Sankhyā: The Indian Journal of Statistics, Series A, Dedicated to the Memory of P. C. Mahalanobis 1973; 35; 4:417-446.

Dehejia, Rajeev and Sadek Wahba. Propensity Score Matching Methods for Non-Experimental Causal Studies. Review of Economics and Statistics 2002; 84; 1:151-161.

Dunn, Thomas, and Douglas Holtz-Eakin. Financial Capital, Human Capital, and the Transition to Self-Employment: Evidence from Intergenerational Links. Journal of Labor Economics 2000; 18; 2:282-305.

Ehrenberg, Ronald G., and Daniel R. Sherman. Employment While in College, Academic Achievement, and Postcollege Outcomes: A Summary of Results. Journal of Human Resources 1987; 22; 1:1-23.

Fairlie, Robert W. The Absence of the African-American Owned Business: An Analysis of the Dynamics of Self-Employment. Journal of Labor Economics 1999; 17; 1:80-108.

Hamermesh, Daniel S., and Stephen G. Donald. The Effect of College Curriculum on Earnings: An Affinity Identifier for Non-Ignorable Non-Response Bias. Journal of Econometrics 2008; 144; 2:479491.

Heckman, James, Hidehiko Ichimura, and Petra Todd. Matching as an Econometric Evaluation Estimator: Evidence from Evaluating a Job Training Programme. Review of Economic Studies 1997; 64; 4: 605-654.

_ Matching as an Econometric Evaluation Estimator. Review of Economic Studies 1998; 65; 2: 261294.

Heckman, James, Hidehiko Ichimura, Jeffrey Smith, and Petra Todd. Characterizing Selection Bias Using Experimental Data. Econometrica 1998; 66; 5:1017-1098.

Hirano, Keisuke, Guido W. Imbens and Geert Ridder. Efficient Estimation of Average Treatment Effects Using the Estimated Propensity Score. Econometrica 2003; 71; 4:1161-1189.

Hout, Michael, and Harvey Rosen. Self-Employment, Family Background, and Race. Journal of Human Resources 2000; 35; 4:670-692.

Imbens, Guido. The Role of the Propensity Score in Estimating Dose-Response Functions. Biometrika 2000; 87; 3:706-710.

— Nonparametric Estimation of Average Treatment Effects under Exogeneity: A Review. The Review of Economics and Statistics 2004; 86; 1:4-29. 
Irandoust, Manuchehr, and Niklas Karlsson. Impact of Preferences, Curriculum and Learning Strategies on Academic Success. Education Economics 2002; 10; 1:41-47.

James, Estelle, Nabeel Alsalam, Joseph C. Conaty, and Duc-Le To. 1989. College Quality and Future Earnings: Where Should You Send Your Child to College? American Economic Review, Vol. Papers and Proceedings of the Hundred and First Annual Meeting of the American Economic Association $1989 ; 79 ; 2: 247-252$.

Kramarz, Francis and Oskar Nordström Skans. With a little help from my...Parents? Family Networks and Youth Labor Market Entry. CREST Working Paper 2007.

Laband, David N. and Lentz, Bernard F. Like father, like son: toward an economic theory of occupational following. Southern Economic Journal 1983; 50; 2:474-493.

_ Self-recruitment in the legal profession. Journal of Labor Economics 1992; 10; 2:182-201.

Lazear, Edward P. Balanced Skills and Entrepreneurship. American Economic Review 2004; 94; 2:208211.

Lechner, Michael. Identification and Estimation of Causal Effects of Multiple Treatments Under the Conditional Independence Assumption. In Econometric Evaluation of Labour Market Policies, ed. Michael Lechner and Friedhelm Pfeiffer 2001; 43-58. Heidelberg: Physica.

Lentz, Bernard F. and David N. Laband. Why so many children of doctors become doctors: nepotism vs. human capital transfers. Journal of Human Resources 1989; 24; 3:396-413.

— Entrepreneurial Success and Occupational Inheritance among Proprietors. Canadian Journal of Economics; 1990; 23; 3:563-579.

Leuven Edwin, and Barbara Sianesi, 2003. PSMATCH2: Stata module to perform full Mahalanobis and propensity score matching, common support graphing, and covariate imbalance testing. Statistical Software Components S432001, Boston College Department of Economics, revised 02 May 2009.

Organisation for Economic Co-operation and Development (OECD). Basic education in Turkey. OECD Publishing; 2008.

Pérez-González, Francisco. Inherited Control and Firm Performance. American Economic Review 2006; 96; 5:1559-1588.

Rosenbaum, Paul and Donald Rubin. The Central Role of the Propensity Score in Observational Studies for Causal Effects. Biometrika 1983; 70; 1:41-55.

_ Constructing a Control Group Using Multivariate Matched Sampling Methods that Incorporate the Propensity Score. The American Statistician 1985; 39; 1:33-38.

Scoppa, Vincenzo. Intergenerational Transfers of Public Sector Jobs: A Shred of Evidence on Nepotism. Public Choice 2009; May.

Spence, Michael. Job market Signaling. The Quarterly Journal of Economics 1973; 87; 3:355-374.

Staiger, Douglas, and James H. Stock. Instrumental Variables Regression with Weak Instruments. Econometrica 1997; 65; 3:557-586.

Tansel, Aysit. Economic Development and Female Labor Force Participation in Turkey: Time-Series Evidence and Cross-Province Estimates. ERC Working Papers no. 0105, 2001; Economic Research Center, Middle East Technical University.

Weisbrod, Burton A., and Peter Karpoff. Monetary Returns to College Education, Student Ability, and College Quality. Review of Economics and Statistics 1968; 50; 4:491-497.

Wise, David. Academic Achievement and Job Performance. American Economic Review; 1975; 65; 3:350-366.

Wooldridge, Jeffrey. Econometric Analysis of Cross Section and Panel Data. Cambridge, MA: MIT Press; 2002. 
Table 1: Comparative Summary Statistics for Surveyed and Non-Surveyed Samples

\begin{tabular}{|c|c|c|c|c|c|c|}
\hline \multirow[b]{2}{*}{ Variable } & \multicolumn{2}{|c|}{$\begin{array}{c}\text { All } \\
(\mathrm{n}=1,122)\end{array}$} & \multicolumn{2}{|c|}{$\begin{array}{c}\text { Surveyed } \\
(\mathrm{n}=499)\end{array}$} & \multicolumn{2}{|c|}{$\begin{array}{c}\text { Non-Surveyed } \\
\quad(\mathrm{n}=623)\end{array}$} \\
\hline & mean & (s.d.) & mean & (s.d.) & mean & (s.d.) \\
\hline Cumulative GPA & 2.42 & $(0.62)$ & 2.54 & $(0.62)$ & 2.31 & $(0.61)$ \\
\hline Course Load & 5.99 & $(1.57)$ & 6.12 & $(1.28)$ & 5.88 & $(1.76)$ \\
\hline Average Course Load & 5.72 & $(1.16)$ & 5.75 & $(1.22)$ & 5.71 & $(1.11)$ \\
\hline Age & 21.49 & $(1.60)$ & 21.38 & $(1.67)$ & 21.58 & $(1.52)$ \\
\hline Female & 0.49 & $(0.50)$ & 0.57 & $(0.49)$ & 0.43 & $(0.49)$ \\
\hline \multicolumn{7}{|l|}{ Major: } \\
\hline Business Administration \& Economics & 0.11 & $(0.31)$ & 0.08 & $(0.27)$ & 0.13 & $(0.33)$ \\
\hline Economics & 0.12 & $(0.32)$ & 0.14 & $(0.34)$ & 0.11 & $(0.32)$ \\
\hline Government & 0.05 & $(0.21)$ & 0.05 & $(0.22)$ & 0.05 & $(0.21)$ \\
\hline Economics (Honors) & 0.02 & $(0.12)$ & 0.01 & $(0.11)$ & 0.02 & $(0.13)$ \\
\hline \multicolumn{7}{|l|}{ Business Administration } \\
\hline \& Economics (Honors) & 0.03 & $(0.16)$ & 0.02 & $(0.15)$ & 0.03 & $(0.18)$ \\
\hline International Finance & 0.12 & $(0.32)$ & 0.10 & $(0.29)$ & 0.13 & $(0.34)$ \\
\hline International Relations & 0.19 & $(0.39)$ & 0.23 & $(0.41)$ & 0.17 & $(0.36)$ \\
\hline Business Administration & 0.36 & $(0.48)$ & 0.37 & $(0.48)$ & 0.36 & $(0.47)$ \\
\hline SSE Score & 253.30 & $(62.26)$ & 263.05 & $(58.77)$ & 245.49 & $(63.90)$ \\
\hline \multicolumn{7}{|l|}{ Entrance Year: } \\
\hline 2002 & 0.30 & $(0.45)$ & 0.23 & $(0.42)$ & 0.36 & $(0.48)$ \\
\hline 2003 & 0.31 & $(0.46)$ & 0.31 & $(0.46)$ & 0.31 & $(0.46)$ \\
\hline 2004 & 0.27 & $(0.44)$ & 0.27 & $(0.44)$ & 0.26 & $(0.44)$ \\
\hline 2005 & 0.12 & $(0.32)$ & 0.19 & $(0.39)$ & 0.07 & $(0.25)$ \\
\hline \multicolumn{7}{|l|}{ Post-Graduation Plans: } \\
\hline Work In Family Business & & & 0.16 & $(0.36)$ & & \\
\hline Start New Business & & & 0.04 & $(0.21)$ & & \\
\hline Work as Employee & & & 0.20 & $(0.39)$ & & \\
\hline Employee $\rightarrow$ Family Firm & & & 0.07 & $(0.25)$ & & \\
\hline Employee $\rightarrow$ New Firm & & & 0.17 & $(0.37)$ & & \\
\hline Graduate School & & & 0.33 & $(0.47)$ & & \\
\hline Other & & & 0.03 & $(0.18)$ & & \\
\hline Hours Studied & & & 1.79 & $(1.07)$ & & \\
\hline Mother's Education & 11.55 & $(4.77)$ & 11.45 & $(4.74)$ & 11.64 & $(4.79)$ \\
\hline Father's Education & 13.37 & $(4.70)$ & 13.36 & $(4.70)$ & 13.38 & $(4.70)$ \\
\hline
\end{tabular}


Table 1 (continued)

\begin{tabular}{|c|c|c|c|c|c|c|}
\hline \multirow[b]{2}{*}{ Variable } & \multicolumn{2}{|c|}{$\begin{array}{c}\text { All } \\
(\mathrm{n}=1,122)\end{array}$} & \multicolumn{2}{|c|}{$\begin{array}{c}\text { Surveyed } \\
(\mathrm{n}=499)\end{array}$} & \multicolumn{2}{|c|}{$\begin{array}{c}\text { Non-Surveyed } \\
\quad(\mathrm{n}=623)\end{array}$} \\
\hline & mean & (s.d.) & mean & (s.d.) & mean & (s.d.) \\
\hline \multicolumn{7}{|l|}{ Mother's Occupation: } \\
\hline Housewife or Does not Work & 0.61 & $(0.48)$ & 0.61 & $(0.48)$ & 0.62 & $(0.48)$ \\
\hline Retired & 0.13 & $(0.33)$ & 0.18 & $(0.38)$ & 0.08 & $(0.27)$ \\
\hline Works as an Employee & 0.15 & $(0.35)$ & 0.10 & $(0.30)$ & 0.18 & $(0.38)$ \\
\hline Self-Employed/Business Owner/Employer & 0.06 & $(0.23)$ & 0.06 & $(0.23)$ & 0.06 & $(0.23)$ \\
\hline Professional & 0.05 & $(0.22)$ & 0.05 & $(0.22)$ & 0.06 & $(0.23)$ \\
\hline \multicolumn{7}{|l|}{ Father's Occupation: } \\
\hline Does not Work & 0.01 & $(0.11)$ & 0.01 & $(0.10)$ & 0.02 & $(0.12)$ \\
\hline Retired & 0.15 & $(0.35)$ & 0.20 & $(0.40)$ & 0.10 & $(0.30)$ \\
\hline Works as an Employee & 0.23 & $(0.42)$ & 0.13 & $(0.33)$ & 0.31 & $(0.46)$ \\
\hline Self-Employed/Business Owner/Employer & 0.44 & $(0.49)$ & 0.38 & $(0.49)$ & 0.49 & $(0.50)$ \\
\hline Professional & 0.16 & $(0.36)$ & 0.27 & $(0.44)$ & 0.07 & $(0.26)$ \\
\hline \multicolumn{7}{|l|}{ Family Income (thousand YTL): } \\
\hline $0-20$ & & & 0.17 & $(0.37)$ & & \\
\hline $20-40$ & & & 0.15 & $(0.35)$ & & \\
\hline $40-60$ & & & 0.10 & $(0.30)$ & & \\
\hline $60-80$ & & & 0.10 & $(0.31)$ & & \\
\hline $80-100$ & & & 0.09 & $(0.28)$ & & \\
\hline $100-120$ & & & 0.06 & $(0.24)$ & & \\
\hline $120-140$ & & & 0.04 & $(0.20)$ & & \\
\hline $140-160$ & & & 0.04 & $(0.18)$ & & \\
\hline $160+$ & & & 0.12 & $(0.32)$ & & \\
\hline
\end{tabular}


Table 2: Parents' Occupations Matched

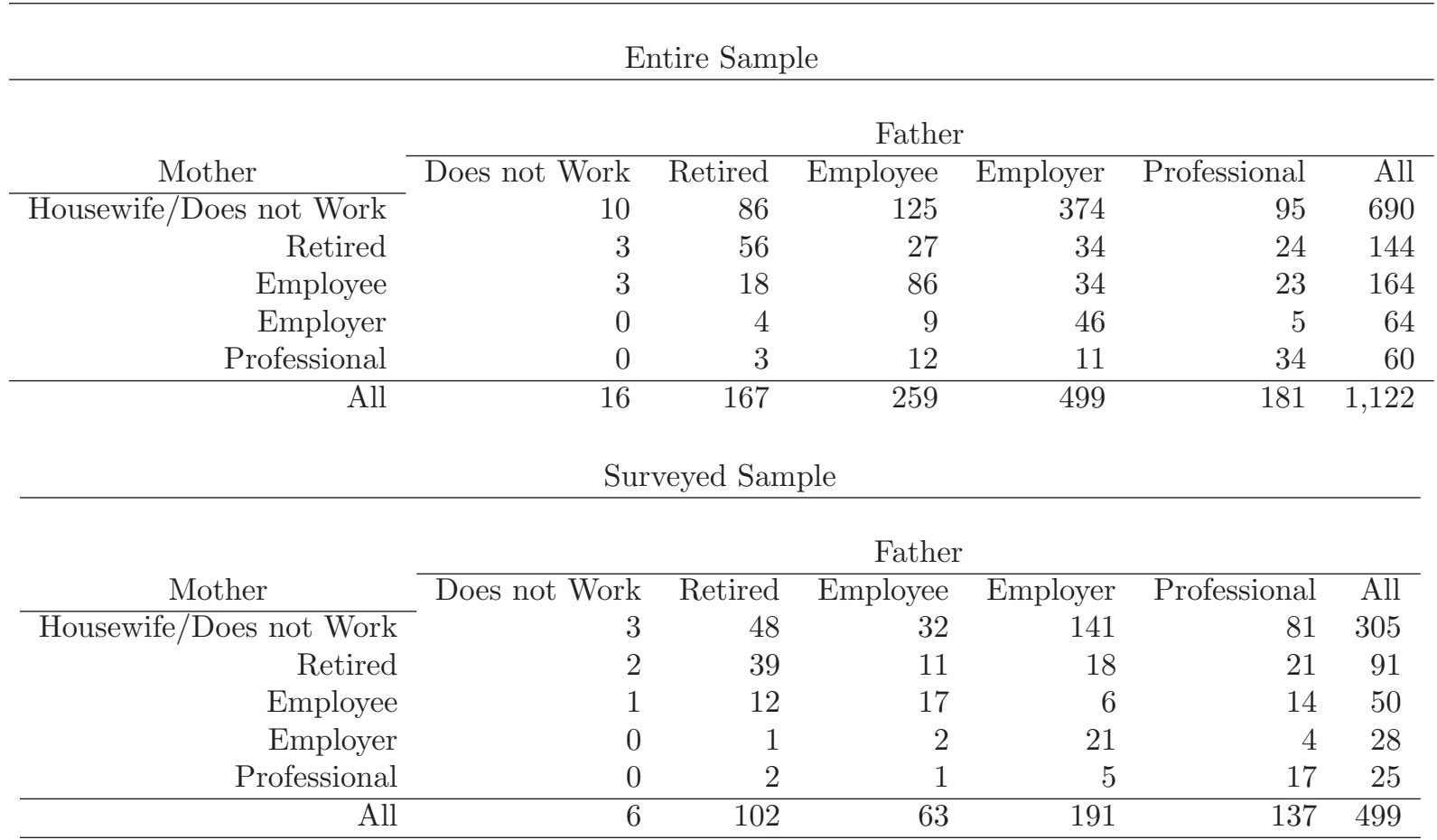


Table 3: The Effect of Self-Employed Parents on College GPA

\begin{tabular}{|c|c|c|c|c|c|c|}
\hline & \multicolumn{6}{|c|}{ GPA } \\
\hline & \multicolumn{3}{|c|}{ Basic Specification } & \multicolumn{3}{|c|}{ Extended Specification } \\
\hline & $\begin{array}{l}\text { All } \\
(1) \\
\end{array}$ & $\begin{array}{c}\text { Men } \\
(2) \\
\end{array}$ & $\begin{array}{c}\text { Women } \\
(3) \\
\end{array}$ & $\begin{array}{l}\text { All } \\
(4) \\
\end{array}$ & $\begin{array}{c}\text { Men } \\
(5)\end{array}$ & $\begin{array}{c}\text { Women } \\
(6)\end{array}$ \\
\hline Control Group Mean & $\begin{array}{c}2.548 \\
{[0.644]}\end{array}$ & $\begin{array}{c}2.451 \\
{[0.644]}\end{array}$ & $\begin{array}{c}2.646 \\
{[0.629]}\end{array}$ & $\begin{array}{c}2.548 \\
{[0.644]}\end{array}$ & $\begin{array}{c}2.451 \\
{[0.644]}\end{array}$ & $\begin{array}{c}2.646 \\
{[0.629]}\end{array}$ \\
\hline $\mathrm{SE}_{\text {father only }}$ & $\begin{array}{c}-0.225^{* * *} \\
(0.037)\end{array}$ & $\begin{array}{c}-0.179^{* * *} \\
(0.054)\end{array}$ & $\begin{array}{c}-0.269^{* * *} \\
(0.052)\end{array}$ & $\begin{array}{c}-0.095^{* * *} \\
(0.034)\end{array}$ & $\begin{array}{c}-0.091^{*} \\
(0.046)\end{array}$ & $\begin{array}{c}-0.089^{*} \\
(0.049)\end{array}$ \\
\hline $\mathrm{SE}_{\text {mother only }}$ & $\begin{array}{l}-0.181 \\
(0.112)\end{array}$ & $\begin{array}{c}-0.349^{* * *} \\
(0.088)\end{array}$ & $\begin{array}{l}-0.145 \\
(0.152)\end{array}$ & $\begin{array}{l}-0.014 \\
(0.101)\end{array}$ & $\begin{array}{c}-0.264^{* * *} \\
(0.093)\end{array}$ & $\begin{array}{c}0.074 \\
(0.146)\end{array}$ \\
\hline $\mathrm{SE}_{\text {both parents }}$ & $\begin{array}{c}-0.375^{* * *} \\
(0.082)\end{array}$ & $\begin{array}{c}-0.459^{* * *} \\
(0.088)\end{array}$ & $\begin{array}{c}-0.252^{*} \\
(0.137)\end{array}$ & $\begin{array}{c}-0.236^{* * *} \\
(0.078)\end{array}$ & $\begin{array}{c}-0.316^{* * *} \\
(0.090)\end{array}$ & $\begin{array}{l}-0.127 \\
(0.124)\end{array}$ \\
\hline Age & $\begin{array}{c}-0.033^{* * *} \\
(0.010)\end{array}$ & $\begin{array}{c}-0.031^{* *} \\
(0.014)\end{array}$ & $\begin{array}{c}-0.026^{*} \\
(0.014)\end{array}$ & $\begin{array}{c}0.015 \\
(0.012)\end{array}$ & $\begin{array}{r}-0.001 \\
(0.017)\end{array}$ & $\begin{array}{c}0.042^{* * *} \\
(0.015)\end{array}$ \\
\hline Income/1,000 & $\begin{array}{c}-0.003^{* * *} \\
(0.0005)\end{array}$ & $\begin{array}{c}-0.003^{* * *} \\
(0.0008)\end{array}$ & $\begin{array}{c}-0.002^{* * *} \\
(0.0007)\end{array}$ & $\begin{array}{c}-0.002^{* * *} \\
(0.0004)\end{array}$ & $\begin{array}{c}-0.002^{* * *} \\
(0.0007)\end{array}$ & $\begin{array}{l}-0.0009 \\
(0.0006)\end{array}$ \\
\hline Additional Controls $\dagger$ & & & & & & \\
\hline Hours Studied & Yes & Yes & Yes & Yes & Yes & Yes \\
\hline SSE Score & No & No & No & Yes & Yes & Yes \\
\hline Exam Year Indicators & No & No & No & Yes & Yes & Yes \\
\hline Exam Score $\times$ Year & No & No & No & Yes & Yes & Yes \\
\hline College Major & No & No & No & Yes & Yes & Yes \\
\hline Parental Education & No & No & No & Yes & Yes & Yes \\
\hline F-stat [p-value $]$ & $\begin{array}{c}15.43 \\
{[<.001]}\end{array}$ & $\begin{array}{c}12.53 \\
{[<.001]}\end{array}$ & $\begin{array}{c}8.49 \\
{[<.001]}\end{array}$ & $\begin{array}{c}4.63 \\
{[0.003]}\end{array}$ & $\begin{array}{c}6.14 \\
{[<.001]}\end{array}$ & $\begin{array}{c}1.40 \\
{[0.243]}\end{array}$ \\
\hline Observations & 1,122 & 573 & 549 & 1,122 & 573 & 549 \\
\hline$R^{2}$ & 0.111 & 0.118 & 0.110 & 0.372 & 0.384 & 0.410 \\
\hline
\end{tabular}


Table 3 (continued)

The Effect of Self-Employed Parents on College GPA

\begin{tabular}{|c|c|c|c|c|c|c|}
\hline & \multicolumn{6}{|c|}{ GPA } \\
\hline & \multicolumn{3}{|c|}{ Basic Specification } & \multicolumn{3}{|c|}{ Extended Specification } \\
\hline & $\begin{array}{l}\text { All } \\
(1)\end{array}$ & $\begin{array}{c}\text { Men } \\
(2)\end{array}$ & $\begin{array}{c}\text { Women } \\
(3)\end{array}$ & $\begin{array}{l}\text { All } \\
(4)\end{array}$ & $\begin{array}{c}\text { Men } \\
(5)\end{array}$ & $\begin{array}{c}\text { Women } \\
(6)\end{array}$ \\
\hline Hours Studied & $\begin{array}{r}-0.029 \\
(0.087)\end{array}$ & $\begin{array}{l}-0.014 \\
(0.027)\end{array}$ & $\begin{array}{l}-0.018 \\
(0.105)\end{array}$ & $\begin{array}{l}-0.038 \\
(0.074)\end{array}$ & $\begin{array}{c}0.019 \\
(0.121)\end{array}$ & $\begin{array}{l}-0.022 \\
(0.090)\end{array}$ \\
\hline Hours Studied ${ }^{2}$ & $\begin{array}{l}0.016 \\
(0.017)\end{array}$ & $\begin{array}{l}-0.014 \\
(0.027)\end{array}$ & $\begin{array}{c}0.021 \\
(0.020)\end{array}$ & $\begin{array}{l}0.018 \\
(0.014)\end{array}$ & $\begin{array}{l}-0.006 \\
(0.023)\end{array}$ & $\begin{array}{c}0.022 \\
(0.016)\end{array}$ \\
\hline $\begin{array}{l}\text { Business Administration } \\
\text { \& Economics }\end{array}$ & & & & $\begin{array}{c}-0.808^{* * *} \\
(0.085)\end{array}$ & $\begin{array}{c}-0.807^{* * *} \\
(0.127)\end{array}$ & $\begin{array}{c}-0.661^{* * *} \\
(0.103)\end{array}$ \\
\hline Economics & & & & $\begin{array}{c}-0.795^{* * *} \\
(0.081)\end{array}$ & $\begin{array}{c}-0.690^{* * *} \\
(0.121)\end{array}$ & $\begin{array}{c}-0.715^{* * *} \\
(0.106)\end{array}$ \\
\hline Government & & & & $\begin{array}{c}-0.568^{* * *} \\
(0.098)\end{array}$ & $\begin{array}{c}-0.411^{* * *} \\
(0.147)\end{array}$ & $\begin{array}{c}-0.601^{* * *} \\
(0.127)\end{array}$ \\
\hline Economics (Honors) & & & & $\begin{array}{l}0.199^{* *} \\
(0.078)\end{array}$ & $\begin{array}{c}0.366^{* * *} \\
(0.116)\end{array}$ & $\begin{array}{c}0.137 \\
(0.112)\end{array}$ \\
\hline International Finance & & & & $\begin{array}{c}-0.814^{* * *} \\
(0.079)\end{array}$ & $\begin{array}{c}-0.614^{* * *} \\
(0.124)\end{array}$ & $\begin{array}{c}-0.924^{* * *} \\
(0.096)\end{array}$ \\
\hline International Relations & & & & $\begin{array}{l}-0.748^{* * *} \\
(0.076)\end{array}$ & $\begin{array}{c}-0.518^{* * *} \\
(0.123)\end{array}$ & $\begin{array}{c}-0.866^{* * *} \\
(0.091)\end{array}$ \\
\hline Business Administration & & & & $\begin{aligned}-0.826^{* * *} & (0.072)\end{aligned}$ & $\begin{array}{c}-0.704^{* * *} \\
(0.113)\end{array}$ & $\begin{array}{c}-0.845^{* * *} \\
\quad(0.086)\end{array}$ \\
\hline SSE Year 2003 & & & & $\begin{array}{c}0.379 \\
(0.380)\end{array}$ & $\begin{array}{c}0.432 \\
(0.590)\end{array}$ & $\begin{array}{c}0.305 \\
(0.568)\end{array}$ \\
\hline SSE Year 2004 & & & & $\begin{array}{c}0.252 \\
(0.381)\end{array}$ & $\begin{array}{l}-0.137 \\
(0.582)\end{array}$ & $\begin{array}{l}0.084 \\
(0.542)\end{array}$ \\
\hline SSE Year 2005 & & & & $\begin{array}{c}0.462 \\
(0.487)\end{array}$ & $\begin{array}{l}0.246 \\
(0.722)\end{array}$ & $\begin{array}{l}0.309 \\
(0.714)\end{array}$ \\
\hline SSE Score & & & & $\begin{array}{c}0.012^{* * *} \\
(0.001)\end{array}$ & $\begin{array}{c}0.011^{* * *} \\
(0.002)\end{array}$ & $\begin{array}{c}0.012^{* * *} \\
(0.002)\end{array}$ \\
\hline SSE Score $\times$ Year 2003 & & & & $\begin{array}{c}-0.006^{* * *} \\
(0.001)\end{array}$ & $\begin{array}{c}-0.006^{* *} \\
(0.003)\end{array}$ & $\begin{array}{c}-0.006^{* *} \\
(0.003)\end{array}$ \\
\hline SSE Score $\times$ Year 2004 & & & & $\begin{array}{c}-0.005^{* * *} \\
(0.001)\end{array}$ & $\begin{array}{l}-0.004 \\
(0.0003)\end{array}$ & $\begin{array}{c}-0.005^{*} \\
(0.003)\end{array}$ \\
\hline SSE Score $\times$ Year 2005 & & & & $\begin{array}{c}-0.006^{* * *} \\
(0.002)\end{array}$ & $\begin{array}{c}-0.005^{*} \\
(0.003)\end{array}$ & $\begin{array}{c}-0.006^{*} \\
(0.003)\end{array}$ \\
\hline Father's Education & & & & $\begin{array}{l}-0.001 \\
(0.042)\end{array}$ & $\begin{array}{l}0.001 \\
(0.005)\end{array}$ & $\begin{array}{l}-0.001 \\
(0.006)\end{array}$ \\
\hline Mother's Education & & & & $\begin{array}{c}-0.007^{*} \\
(0.003)\end{array}$ & $\begin{array}{c}-0.011^{* *} \\
(0.005)\end{array}$ & $\begin{array}{l}-0.005 \\
(0.005)\end{array}$ \\
\hline
\end{tabular}


Table 4: Testing the Equality of the SSE Scores by Parents' Occupations Contrasts by Parental Self-Employment Status

\begin{tabular}{lcccc} 
& Control & Control vs. & Control vs. & Control vs. \\
\cline { 3 - 5 } & Mean & $S E_{\text {father only }}$ & $S E_{\text {mother only }}$ & $S E_{\text {both parents }}$ \\
\hline SSE Score & 256.408 & 6.118 & 25.490 & 5.622 \\
& $\{64.569\}$ & $(3.877)$ & $(15.486)$ & $(9.765)$ \\
t-Stat & & 1.578 & 1.646 & 0.575 \\
& & {$[0.115]$} & {$[0.103]$} & {$[0.565]$} \\
Observations & 605 & 453 & 18 & 46 \\
\hline
\end{tabular}

NOTE: Standard deviation is given in braces. Standard errors are reported in parentheses. p-values for t-stats are reported in brackets. Control group includes students who do not have any self-employed parents. ${ }^{* * *},{ }^{* *}$ and ${ }^{*}$ indicate respectively $1 \%, 5 \%$ and $10 \%$ significance levels. 
Table 5: The Impact of Professional Parents on College GPA

\begin{tabular}{|c|c|c|}
\hline & \multicolumn{2}{|c|}{ GPA } \\
\hline & Basic Specification & Extended Specification \\
\hline (i) $\mathrm{SE}_{\text {father only }}$ & $\begin{array}{c}-0.270^{* * *} \\
(0.042)\end{array}$ & $\begin{array}{c}-0.091^{* *} \\
(0.038)\end{array}$ \\
\hline \multirow{2}{*}{ (ii) $\mathrm{SE}_{\text {mother only }}$} & $-0.250^{*}$ & -0.056 \\
\hline & $(0.142)$ & $(0.126)$ \\
\hline \multirow{2}{*}{ (iii) $\mathrm{SE}_{\text {both parents }}$} & $-0.418^{* * *}$ & $-0.221^{* * *}$ \\
\hline & $(0.082)$ & $(0.078)$ \\
\hline \multirow[t]{2}{*}{ (iv) $\mathrm{SE}_{\text {father }} \wedge \mathrm{Pro}_{\text {mother }}$} & -0.237 & -0.071 \\
\hline & $(0.148)$ & $(0.104)$ \\
\hline \multirow[t]{2}{*}{ (v) $\mathrm{SE}_{\text {mother }} \wedge \operatorname{Pro}_{\text {father }}$} & $-0.260^{* *}$ & 0.007 \\
\hline & $(0.109)$ & $(0.116)$ \\
\hline \multirow[t]{2}{*}{ (vi) $\operatorname{Pro}_{\text {father only }}$} & $-0.127^{* *}$ & 0.017 \\
\hline & $(0.059)$ & $(0.051)$ \\
\hline \multirow[t]{2}{*}{ (vii) $\mathrm{PrO}_{\text {mother only }}$} & -0.199 & -0.031 \\
\hline & $(0.131)$ & $(0.141)$ \\
\hline \multirow[t]{2}{*}{ (viii) $\mathrm{Pro}_{b o t h}$ parents } & $-0.179^{*}$ & -0.018 \\
\hline & $(0.101)$ & $(0.085)$ \\
\hline \multirow[t]{2}{*}{ Family Income/1,000 } & $-0.003^{* * *}$ & $-0.001^{* * *}$ \\
\hline & $(0.0005)$ & $(0.0004)$ \\
\hline \multirow[t]{2}{*}{ Age } & $-0.031^{* * *}$ & $0.020^{*}$ \\
\hline & $(0.010)$ & $(0.012)$ \\
\hline \multirow[t]{2}{*}{ Female } & $0.145^{* * *}$ & $0.144^{* * *}$ \\
\hline & $(0.036)$ & $(0.030)$ \\
\hline \multicolumn{3}{|l|}{ Additional Controls $\dagger$} \\
\hline Hours Studied & Yes & Yes \\
\hline Exam Score × Year & No & Yes \\
\hline Exam Year Indicators & No & Yes \\
\hline College Major & No & Yes \\
\hline Parental Education & No & Yes \\
\hline \multicolumn{3}{|l|}{ F-Statistics and $p$-values } \\
\hline$H_{o}:(i)=\ldots=($ viii $)=0$ & $6.56(<.001)$ & $1.71(.092)$ \\
\hline$H_{o}:(i)=(i i)=(i i i)=0$ & $16.91(<.001)$ & $3.48(.015)$ \\
\hline$H_{o}:($ iv $)=\ldots=(v i i i)=0$ & $2.59(.024)$ & $0.16(.978)$ \\
\hline$H_{o}:(v i)=(v i i)=(v i i i)=0$ & $2.66(.047)$ & $0.08(.970)$ \\
\hline Observations & 1,122 & 1,122 \\
\hline$R^{2}$ & .129 & .384 \\
\hline
\end{tabular}

NOTE: The dependent variable is the individual GPA. Standard errors are given in parentheses. The linearized standard errors are derived from a consistent variance-covariance matrix using Huber-White sandwich estimators. ${ }^{* * *},{ }^{* *}$ and * indicate respectively $1 \%, 5 \%$ and $10 \%$ significance levels. The indicator variables for the Business Administration Economics Combined Honors major and test year 2002 are omitted.

†See next page for the parameter estimates of these variables. 
Table 5 (continued)

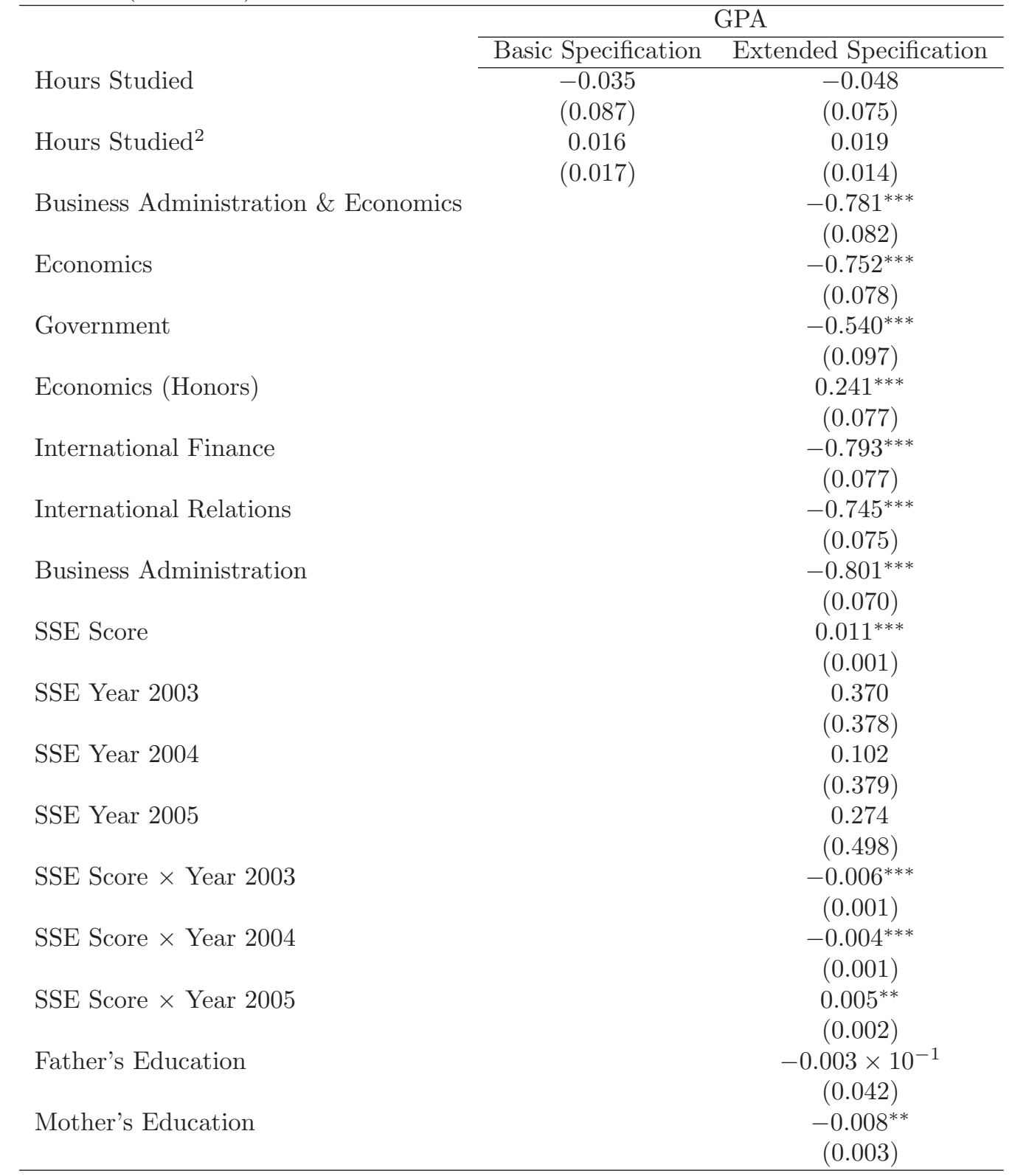


Table 6: The Determinants of Post-Graduation Plans: Marginal Effects after Multinomial Logit

\begin{tabular}{|c|c|c|c|c|c|c|}
\hline & \multicolumn{6}{|c|}{ (Base Outcome=Plan to be an Employee) } \\
\hline & $\begin{array}{l}\text { Family } \\
\text { Business }\end{array}$ & $\begin{array}{c}\text { New } \\
\text { Business }\end{array}$ & $\begin{array}{c}\text { Employee } \rightarrow \\
\text { Family Business }\end{array}$ & $\begin{array}{l}\text { Employee } \rightarrow \\
\text { New Business }\end{array}$ & $\begin{array}{c}\text { Graduate } \\
\text { School }\end{array}$ & Other \\
\hline (i) $\mathrm{SE}_{\text {father only }}$ & $\begin{array}{c}0.265^{* * *} \\
(0.049)\end{array}$ & $\begin{array}{l}0.005 \\
(0.004)\end{array}$ & $\begin{array}{c}0.071^{* *} \\
(0.031)\end{array}$ & $\begin{array}{l}-0.019 \\
(0.012)\end{array}$ & $\begin{array}{c}-0.103^{*} \\
(0.057)\end{array}$ & $\begin{array}{c}-0.037^{*} \\
(0.027)\end{array}$ \\
\hline (ii) $\mathrm{SE}_{\text {both parents }}$ & $\begin{array}{c}0.616^{* * *} \\
(0.104)\end{array}$ & $\begin{array}{l}-0.029^{* * *} \\
(0.009)\end{array}$ & $\begin{array}{c}0.148 \\
(0.097)\end{array}$ & $\begin{array}{c}-0.212^{* * *} \\
(0.021)\end{array}$ & $\begin{array}{c}-0.367^{* * *} \\
(0.051)\end{array}$ & $\begin{array}{c}0.004 \\
(0.022)\end{array}$ \\
\hline Age & $\begin{array}{l}-0.008 \\
(0.011)\end{array}$ & $\begin{array}{c}-0.004^{* *} \\
(0.002)\end{array}$ & $\begin{array}{l}-0.016 \\
(0.010)\end{array}$ & $\begin{array}{c}0.001 \\
(0.005)\end{array}$ & $\begin{array}{l}0.015 \\
(0.019)\end{array}$ & $\begin{array}{l}-0.002 \\
(0.003)\end{array}$ \\
\hline Female & $\begin{array}{c}-0.078^{* *} \\
(0.032)\end{array}$ & $\begin{array}{c}-0.008^{*} \\
(0.004)\end{array}$ & $\begin{array}{l}-0.020 \\
(0.025)\end{array}$ & $\begin{array}{l}-0.008 \\
(0.013)\end{array}$ & $\begin{array}{c}0.039 \\
(0.053)\end{array}$ & $\begin{array}{l}-0.003 \\
(0.012)\end{array}$ \\
\hline Income $/ 1,000$ & $\begin{array}{c}0.0009^{* * *} \\
(0.0002)\end{array}$ & $\begin{array}{c}0.0002 \\
(0.0003)\end{array}$ & $\begin{array}{c}0.0002 \\
(0.0002)\end{array}$ & $\begin{array}{l}0.0003 \\
(0.002)\end{array}$ & $\begin{array}{l}-0.0004 \\
(0.0005)\end{array}$ & $\begin{array}{c}-0.0003^{* *} \\
(0.0001)\end{array}$ \\
\hline SSE Score & $\begin{array}{c}-0.008^{* * *} \\
(0.002)\end{array}$ & $\begin{array}{c}-0.0008^{* * *} \\
(0.0003)\end{array}$ & $\begin{array}{c}-0.003^{* * *} \\
(0.001)\end{array}$ & $\begin{array}{l}-0.0005 \\
(0.0008)\end{array}$ & $\begin{array}{c}0.011^{* * *} \\
(0.003)\end{array}$ & $\begin{array}{l}-0.001 \\
(0.008)\end{array}$ \\
\hline Year 2003 & $\begin{array}{c}-0.539^{* *} \\
(0.280)\end{array}$ & $\begin{array}{l}-0.177 \\
(0.233)\end{array}$ & $\begin{array}{l}-0.015 \\
(0.035)\end{array}$ & $\begin{array}{l}-0.029 \\
(0.038)\end{array}$ & $\begin{array}{c}0.962^{* * *} \\
(0.045)\end{array}$ & $\begin{array}{l}-0.023 \\
(0.041)\end{array}$ \\
\hline Year 2004 & $\begin{array}{l}-0.283 \\
(0.241)\end{array}$ & $\begin{array}{l}-0.221 \\
(0.313)\end{array}$ & $\begin{array}{c}0.035 \\
(0.024)\end{array}$ & $\begin{array}{l}-0.077 \\
(0.089)\end{array}$ & $\begin{array}{c}0.530 \\
(0.633)\end{array}$ & $\begin{array}{l}-0.094 \\
(0.132)\end{array}$ \\
\hline Year 2005 & $\begin{array}{c}-0.339^{* *} \\
(0.160)\end{array}$ & $\begin{array}{l}-0.021 \\
(0.027)\end{array}$ & $\begin{array}{l}-0.095 \\
(0.084)\end{array}$ & $\begin{array}{l}-0.043 \\
(0.038)\end{array}$ & $\begin{array}{l}-0.115 \\
(0.476)\end{array}$ & $\begin{array}{l}-0.147 \\
(0.164)\end{array}$ \\
\hline SSE $\times$ Year 2003 & $\begin{array}{c}0.007^{* * *} \\
(0.002)\end{array}$ & $\begin{array}{l}0.0007^{* *} \\
(0.0002)\end{array}$ & $\begin{array}{c}0.002 \\
(0.002)\end{array}$ & $\begin{array}{c}0.006 \\
(0.009)\end{array}$ & $\begin{array}{c}-0.012^{* * *} \\
(0.003)\end{array}$ & $\begin{array}{c}0.001 \\
(0.001)\end{array}$ \\
\hline SSE $\times$ Year 2004 & $\begin{array}{l}0.005^{* *} \\
(0.002)\end{array}$ & $\begin{array}{l}0.0007^{* *} \\
(0.0003)\end{array}$ & $\begin{array}{c}0.001 \\
(0.001)\end{array}$ & $\begin{array}{c}0.008 \\
(0.009)\end{array}$ & $\begin{array}{c}-0.007^{*} \\
(0.004)\end{array}$ & $\begin{array}{c}0.001 \\
(0.001)\end{array}$ \\
\hline $\mathrm{SSE} \times$ Year 2005 & $\begin{array}{c}0.006^{* * *} \\
(0.002)\end{array}$ & $\begin{array}{c}0.0005 \\
(0.0003)\end{array}$ & $\begin{array}{l}0.002^{*} \\
(0.001)\end{array}$ & $\begin{array}{c}0.003 \\
(0.009)\end{array}$ & $\begin{array}{c}-0.006^{*} \\
(0.003) \\
\end{array}$ & $\begin{array}{c}0.001 \\
(0.001)\end{array}$ \\
\hline $\begin{array}{l}\chi^{2}\left(\operatorname{Pr}>\chi^{2}\right) \\
\text { Pseudo } R^{2} \\
\text { Log Pseudolikelihood }\end{array}$ & $\begin{array}{c}23,806(<.001) \\
.152 \\
-727.35\end{array}$ & & & & & \\
\hline $\begin{array}{l}\chi^{2} \text { Stat for }(i)=(i i)=0 \\
\text { [degrees of freedom] } \\
\left(\operatorname{Pr}>\chi^{2}\right)\end{array}$ & $\begin{array}{c}17,600 \\
{[12]} \\
(<.001)\end{array}$ & & & & & \\
\hline $\begin{array}{l}\text { Choice Spec. } \chi^{2} \text { Stat } \\
\text { [degrees of freedom] } \\
(i)=(i i)=0\left(\operatorname{Pr}>\chi^{2}\right)\end{array}$ & $\begin{array}{c}53.94 \\
{[2]} \\
(<.001) \\
\end{array}$ & $\begin{array}{c}4157.06 \\
{[2]} \\
(<.001) \\
\end{array}$ & $\begin{array}{c}19.48 \\
{[2]} \\
(<.001) \\
\end{array}$ & $\begin{array}{c}3,575 \\
{[2]} \\
(<.001) \\
\end{array}$ & $\begin{array}{c}4.03 \\
{[2]} \\
(.133) \\
\end{array}$ & $\begin{array}{c}3.80 \\
{[2]} \\
(.149) \\
\end{array}$ \\
\hline Hausman Tests O & IIA Assumption & $\begin{array}{c}\mathrm{H}_{0}=\text { Odds }(\mathrm{Ou} \\
\chi^{2}\end{array}$ & $\begin{array}{l}\text { ome-J vs Outcom } \\
\text { df. }\end{array}$ & $\begin{array}{l}\text { K) are Indep. } \\
\left(P>\chi^{2}\right)\end{array}$ & $\begin{array}{l}\text { Other Alter } \\
\text { Evidence }\end{array}$ & atives \\
\hline Work in & the Family Firm & .000 & 2 & $>.999$ & for $H_{0}$ & \\
\hline & tart a New Firm & .000 & 1 & $>.999$ & for $H_{0}$ & \\
\hline Employ & $\mathrm{ee} \rightarrow$ Family Firm & .000 & 2 & $>.999$ & for $H_{0}$ & \\
\hline Emp & oyee $\rightarrow$ New Firm & .000 & 1 & $>.999$ & for $H_{0}$ & \\
\hline & Graduate School & .000 & 2 & $>.999$ & for $H_{0}$ & \\
\hline & Other & .000 & 2 & $>.999$ & for $H_{0}$ & \\
\hline Wor & as an Employee & .000 & 2 & $>.999$ & for $H_{0}$ & \\
\hline
\end{tabular}


Table 7: The Determinants of Entrepreneurial Intent Corrected for Survey Non-Response Bias: Marginal Effects After Maximum Likelihood Probit Model with Sample Selection

\begin{tabular}{|c|c|c|c|c|c|c|}
\hline & \multicolumn{3}{|c|}{ Model 1} & \multicolumn{3}{|c|}{ Model 2} \\
\hline & \multirow[b]{2}{*}{$\operatorname{Pr}($ Surveyed) } & \multicolumn{2}{|c|}{$\operatorname{Pr}$ (First-Degree Entrepreneur) } & \multirow[b]{2}{*}{$\operatorname{Pr}($ Surveyed) } & \multicolumn{2}{|c|}{$\operatorname{Pr}($ First-Degree Entrepreneur $)$} \\
\hline & & Not Corrected & Corrected & & Not Corrected & Corrected \\
\hline Current Course Load & $\begin{array}{c}0.089^{* * *} \\
(0.026)\end{array}$ & & & $\begin{array}{c}0.090^{* * *} \\
(0.027)\end{array}$ & & \\
\hline$\left(1 \leq \mathrm{SE}_{\text {Parent }}\right)$ & $\begin{array}{c}-0.201^{*} \\
(0.122)\end{array}$ & $\begin{array}{c}0.262^{* * *} \\
(0.057)\end{array}$ & $\begin{array}{c}0.346^{* *} \\
(0.142)\end{array}$ & & & \\
\hline Female $\times\left(1 \leq \mathrm{SE}_{\text {Parent }}\right)$ & $\begin{array}{l}-0.178 \\
(0.158)\end{array}$ & $\begin{array}{l}-0.023 \\
(0.063)\end{array}$ & $\begin{array}{l}-0.023 \\
(0.094)\end{array}$ & & & \\
\hline $\mathrm{SE}_{\text {father only }}$ & & & & $\begin{array}{c}-0.267^{* *} \\
(0.116)\end{array}$ & $\begin{array}{c}0.273^{* * *} \\
(0.064)\end{array}$ & $\begin{array}{c}0.354^{* *} \\
(0.162)\end{array}$ \\
\hline $\mathrm{SE}_{\text {both parents }}$ & & & & $\begin{array}{c}0.153 \\
(0.268)\end{array}$ & $\begin{array}{c}0.595^{* * *} \\
(0.137)\end{array}$ & $\begin{array}{c}0.594^{* * *} \\
(0.159)\end{array}$ \\
\hline Female $\times \mathrm{SE}_{\text {father only }}$ & & & & $\begin{array}{l}-0.089 \\
(0.163)\end{array}$ & $\begin{array}{l}-0.020 \\
(0.064)\end{array}$ & $\begin{array}{l}-0.026 \\
(0.092)\end{array}$ \\
\hline Female $\times \mathrm{SE}_{\text {both parents }}$ & & & & $\begin{array}{l}-0.518 \\
(0.495)\end{array}$ & $\begin{array}{l}-0.056 \\
(0.098)\end{array}$ & $\begin{array}{l}-0.062 \\
(0.169)\end{array}$ \\
\hline Average Course Load & $\begin{array}{c}-0.177^{* * *} \\
(0.041)\end{array}$ & $\begin{array}{l}-0.018 \\
(0.016)\end{array}$ & $\begin{array}{l}-0.037 \\
(0.430)\end{array}$ & $\begin{array}{c}-0.182^{* * *} \\
(0.041)\end{array}$ & $\begin{array}{c}0.017 \\
(0.015)\end{array}$ & $\begin{array}{c}0.035 \\
(0.047)\end{array}$ \\
\hline Age & $\begin{array}{l}0.058^{* *} \\
(0.030)\end{array}$ & $\begin{array}{c}-0.026^{* *} \\
(0.011)\end{array}$ & $\begin{array}{l}-0.040 \\
(0.028)\end{array}$ & $\begin{array}{l}0.057^{*} \\
(0.030)\end{array}$ & $\begin{array}{c}-0.024^{* *} \\
(0.011)\end{array}$ & $\begin{array}{l}-0.038 \\
(0.031)\end{array}$ \\
\hline Female & $\begin{array}{c}0.493^{* * *} \\
(0.107)\end{array}$ & $\begin{array}{c}-0.094^{*} \\
(0.053)\end{array}$ & $\begin{array}{r}-0.160 \\
(0.152)\end{array}$ & $\begin{array}{c}0.466^{* * *} \\
(0.105)\end{array}$ & $\begin{array}{c}-0.089^{*} \\
(0.052)\end{array}$ & $\begin{array}{r}-0.149 \\
(0.157)\end{array}$ \\
\hline SSE Score & $\begin{array}{l}-0.002 \\
(0.004)\end{array}$ & $\begin{array}{c}-0.009^{* * *} \\
(0.002)\end{array}$ & $\begin{array}{c}-0.014^{* * *} \\
(0.005)\end{array}$ & $\begin{array}{l}-0.002 \\
(0.004)\end{array}$ & $\begin{array}{c}-0.010^{* * *} \\
(0.002)\end{array}$ & $\begin{array}{c}-0.014^{* *} \\
(0.006)\end{array}$ \\
\hline Year 2003 & $\begin{array}{c}0.451 \\
(0.935)\end{array}$ & $\begin{array}{c}-0.757^{* * *} \\
(0.172)\end{array}$ & $\begin{array}{c}-0.866^{* * *} \\
(0.170)\end{array}$ & $\begin{array}{c}0.501 \\
(0.923)\end{array}$ & $\begin{array}{c}-0.799 * * * \\
(0.156)\end{array}$ & $\begin{array}{c}-0.891^{* * *} \\
(0.155)\end{array}$ \\
\hline Year 2004 & $\begin{array}{c}-0.756 \\
(1.03)\end{array}$ & $\begin{array}{c}-0.566^{* *} \\
(0.230)\end{array}$ & $\begin{array}{c}-0.689^{* * *} \\
(0.266)\end{array}$ & $\begin{array}{c}-0.766 \\
(1.03)\end{array}$ & $\begin{array}{c}-0.591^{* *} \\
(0.233)\end{array}$ & $\begin{array}{c}-0.705^{* * *} \\
(0.270)\end{array}$ \\
\hline Year 2005 & $\begin{array}{c}-0.366 \\
(1.23)\end{array}$ & $\begin{array}{c}-0.362^{* *} \\
(0.146)\end{array}$ & $\begin{array}{l}-0.415 \\
(0.276)\end{array}$ & $\begin{array}{c}-0.334 \\
(1.23)\end{array}$ & $\begin{array}{c}-0.404^{* * *} \\
(0.155)\end{array}$ & $\begin{array}{r}-0.431 \\
(0.296)\end{array}$ \\
\hline $\mathrm{SSE} \times$ Year 2003 & $\begin{array}{c}0.0004 \\
(0.0004)\end{array}$ & $\begin{array}{c}0.009^{* * *} \\
(0.002)\end{array}$ & $\begin{array}{c}0.012^{* *} \\
(0.005)\end{array}$ & $\begin{array}{l}0.0001 \\
(0.004)\end{array}$ & $\begin{array}{c}0.009^{* * *} \\
(0.002)\end{array}$ & $\begin{array}{l}0.012^{* *} \\
(0.005)\end{array}$ \\
\hline $\mathrm{SSE} \times$ Year 2004 & $\begin{array}{c}0.005 \\
(0.005)\end{array}$ & $\begin{array}{c}0.007^{* * *} \\
(0.002)\end{array}$ & $\begin{array}{c}0.010^{* *} \\
(0.004)\end{array}$ & $\begin{array}{c}0.005 \\
(0.005)\end{array}$ & $\begin{array}{c}0.007^{* * *} \\
(0.002)\end{array}$ & $\begin{array}{c}0.010^{* *} \\
(0.004)\end{array}$ \\
\hline $\mathrm{SSE} \times$ Year 2005 & $\begin{array}{c}0.006 \\
(0.005)\end{array}$ & $\begin{array}{c}0.007^{* * *} \\
(0.002)\end{array}$ & $\begin{array}{c}0.009^{* *} \\
(0.003)\end{array}$ & $\begin{array}{c}0.007 \\
(0.005) \\
\end{array}$ & $\begin{array}{c}0.007^{* * *} \\
(0.002)\end{array}$ & $\begin{array}{c}0.010^{* *} \\
(0.004)\end{array}$ \\
\hline Number of Obs. & 1,108 & 485 & 1,108 & 1,108 & 485 & 1,108 \\
\hline Censored Obs. & 623 & & 623 & 623 & & 623 \\
\hline Uncensored Obs. & 485 & & 485 & 485 & & 485 \\
\hline $\begin{array}{l}\text { Log pseudolikelihood } \\
\widehat{\rho} \text { (s.e.) }\end{array}$ & $\begin{array}{c}-891.1 \\
-0.323(0.703)\end{array}$ & -191.3 & -891.1 & $\begin{array}{c}-885.2 \\
-0.303(0.766)\end{array}$ & -186.2 & -885.2 \\
\hline $\begin{array}{l}\text { Wald Test for Indep. Eqns. } \\
\left.(\rho=0) \chi^{2}(1) \text { ( } p \text {-value }\right)\end{array}$ & $.18(.66)$ & & & $.14(.71)$ & & \\
\hline $\begin{array}{l}\chi^{2} \text {-Stat for SE Parent } \\
\text { Dummies }(p \text {-value })\end{array}$ & & & & $\begin{array}{l}32.81 \\
(<.001)\end{array}$ & $\begin{array}{l}31.77 \\
(<.001)\end{array}$ & $\begin{array}{c}32.81 \\
(<.001)\end{array}$ \\
\hline $\begin{array}{l}\chi^{2} \text {-Stat for SE Parent } \\
\text { Dummies } \times \text { Female }(p \text {-value })\end{array}$ & $\begin{array}{c}57.23 \\
(<.001)\end{array}$ & $\begin{array}{c}43.45 \\
(<.001)\end{array}$ & $\begin{array}{c}57.23 \\
(<.001)\end{array}$ & $\begin{array}{l}64.52 \\
(<.001)\end{array}$ & $\begin{array}{l}53.08 \\
(<.001)\end{array}$ & $\begin{array}{c}64.52 \\
(<.001)\end{array}$ \\
\hline
\end{tabular}

NOTE: Standard errors are given in parentheses. The linearized standard errors are derived from a consistent variancecovariance matrix using Huber-White sandwich estimators. ${ }^{* * *}$, ${ }^{* *}$ and * indicate respectively $1 \%, 5 \%$ and $10 \%$ significance levels. The indicator variable for test year 2002 is omitted. The results reported for the entrepreneurial intent equation estimations are marginal effects rather than coefficients, while the results for the survey response equation are the coefficients after probit estimation. 


\section{Appendix A: Propensity Score Matching Methods}

The basic idea of matching involves pairing "treatment" and "comparison" units that are similar in terms of all relevant observable characteristics, $X$. In our context, the students who have at least one non-professional self-employed parent constitute the treatment group, while the comparison group includes those who do not. ${ }^{39}$

Matching based on observable characteristics is an attractive idea. However, for a high dimensional $X$, conditioning on all observable characteristics makes it hard to find matches for each cell, a problem known as the "curse of dimensionality." To solve this problem, as proposed by Rosenbaum and Rubin (1983), we use one-dimensional propensity scores. Let the binary treatment indicator $D$ equal one if a student has at least one nonprofessional self-employed parent and zero otherwise. ${ }^{40}$ In our case, the propensity score is the estimated probability of having at least one self-employed parent, $P(D=1 \mid X)=$ $P(X)$, given the observed characteristics $X .{ }^{41}$ We use a probit model to calculate the propensity score $\hat{P}(X)$.

The main parameter of interest is the average effect of treatment on the treated, which we denote ATT:

$$
A T T=E(G P A(1)-G P A(0) \mid D=1)=E(G P A(1) \mid D=1)-E(G P A(0) \mid D=1) .
$$

\footnotetext{
${ }^{39}$ One could also consider a multiple treatment model (see Imbens [2000] and Lechner [2001] for discussion) in which students with only a non-professional self-employed mother, only a non-professional self-employed father, and two non-professional self-employed parents make up three treatment groups, while those with no non-professional self-employed parents make up the comparison group. We limit our attention to the binary treatment case to keep the model simple.

${ }^{40}$ Our definition of self-employed parents excludes parents with professional occupations such as doctors, lawyers, and accountants. To save space we use "self-employed" instead of "non-professional selfemployed."

${ }^{41} \mathrm{X}$ is a vector of observed covariates affecting both college GPA and the treatment.
} 
While the first term $E(G P A(1) \mid D=1)$ is observed, $E(G P A(0) \mid D=1)$ is not observed. Under the conditional independence assumption (CIA) one can replace $E(G P A(0) \mid D=1)$ with $E(G P A(0) \mid D=0)$.

The CIA states that the treatment status is random conditional on the propensity score, $\mathrm{P}(\mathrm{X})$.

$$
G P A(0) \perp D \mid P(X) \quad(C I A) .
$$

In addition, we make the common support assumption (CSA):

$$
0<P(D=1 \mid X)<1 \text { for all } X \quad(C S A)
$$

The CSA implies that for matching to be implemented, we should not have persons with some characteristics $X$ always or never appear in the treated group.

Given that CIA and CSA hold, one can write the propensity score matching (PSM) estimator for ATT in equation (9) as follows ${ }^{42}$ :

$$
A T T_{P S M}=E_{P(X) \mid D=1}\{E[G P A(1) \mid D=1, P(X)]-E[G P A(0) \mid D=0, P(X)]\} .
$$

There are a variety of PSM estimators. ${ }^{43}$ Asymptotically, different matching algorithms yield the same estimates; however, in finite samples they may generate different estimates. To test the robustness of our results we use various PSM estimators: the

\footnotetext{
${ }^{42}$ For detailed discussion of PSM, see for example Rosenbaum and Rubin (1983), Heckman, Ichimura and Todd (1997, 1998), Heckman, Ichimura, Smith and Todd (1998), Hirano, Imbens and Ridder (2003), Imbens (2004), and Lechner (2001).

${ }^{43}$ See Caliendo and Kopeinig (2008) for an extensive survey on the PSM methods.
} 
nearest neighbor(NN) estimator, the Gaussian and the Epanechnikov kernel estimators. ${ }^{44}$

In the NN matching framework bad matches are inevitable if the nearest comparison group member, in terms of propensity score, is far away. To solve this issue and increase the match quality we combine the NN estimator with a caliper and a radius. The caliper describes a tolerance level around each treated unit within which the comparison unit can be chosen. ${ }^{45}$ If there is no comparison group member within the caliper interval, the treated observation is excluded from the estimation. ${ }^{46}$ Similar to caliper matching, radius matching, as suggested by Dehejia and Wahba (2002), describes a propensity score interval around each treated unit and uses all the comparison group members within each caliper. Similarly, to avoid bad matches we combine kernel estimators with a bandwidth. We calculate estimates by two different caliper, radius and bandwidth sizes. ${ }^{47}$

Table A1 reports probit estimates for the presence of at least one self-employed parent in three samples. Since the impact of treatment may be heterogenous between men and women, we conduct matching on men's and women's sub-samples separately as well as on the pooled sample. ${ }^{48}$ We empirically test the common support condition by examining the estimated propensity score distributions for the treated and comparison groups. Figure

\footnotetext{
${ }^{44}$ See Becker and Ichino (2002) for the technical details on the NN and the kernel estimators. There is a trade-off between the bias and variance between two groups of estimators. To construct the counterfactual, the NN estimator matches each treated student with a member of the comparison group who has the closest propensity score. The kernel estimators, on the other hand, match each treated student with a weighted average of several, even all, members of the comparison group. As a result, the NN estimator implies lower bias and higher variance, while kernel estimators imply higher bias and lower variance.

${ }^{45}$ See Cochran and Rubin (1973).

${ }^{46}$ Excluding the treated observations that lack a comparison member within the caliper interval changes the nature of the parameter estimated. In this case, the estimate gives the mean effect of the treatment on the treated for those there are comparison group members within their caliper.

${ }^{47}$ Based on our inspection of the data and as suggested in Cochran and Rubin (1973) and Rosenbaum and Rubin (1985), we use two caliper/radius/bandwidth sizes, 0.1 and 0.05 .

${ }^{48}$ See, e.g., Heckman, Ichimura and Todd $(1997,1998)$ and Heckman, Ichimura, Smith and Todd (1998).
} 
1 shows that the propensity score distributions for the treatment and comparison groups are very similar and the common support condition holds.

Our PSM estimates of the impact of having at least one self-employed parent on GPA appear in Table A2. ${ }^{49}$ As previously mentioned, we implement the NN estimator combined with two caliper or radius widths and the Gaussian and the Epanechnikov kernel estimators combined with two bandwidths. The OLS estimates, which are presented in the first row, are statistically significant, $-0.164,-0.155$ and -0.164 in the pooled, men's and women's samples, respectively. The PSM estimates ranging from $-0.137(-0.089)$ to $-0.183(-0.150)$ for women (men) are very similar to the OLS estimates. Moreover, the estimates are not affected when we change bandwidth, caliper or radius sizes.

\footnotetext{
${ }^{49}$ We use the STATA codes by Becker and Ichino (2002) and Leuven and Sianesi (2003) to implement PSM estimators.
} 
Table A1: Propensity Score Coefficient Estimates

\begin{tabular}{lccc}
\hline & \multicolumn{3}{c}{ Pr(At least One SE Parent) } \\
\cline { 2 - 4 } & All & Men & Women \\
& $(1)$ & $(2)$ & $(3)$ \\
\cline { 2 - 4 } Intercept & & & \\
Age & $8.778^{* * *}$ & $10.442^{* * *}$ & $7.632^{* * *}$ \\
& $(1.073)$ & $(1.523)$ & $(1.564)$ \\
Mother's Education & $-0.159^{* * *}$ & $-0.224^{* * *}$ & $-0.112^{* *}$ \\
& $(0.031)$ & $(0.046)$ & $(0.045)$ \\
Father's Education & -0.004 & -0.011 & 0.005 \\
& $-0.051^{* * *}$ & $(0.014)$ & $(0.015)$ \\
SSE Score & $(0.010)$ & $\left(0.018^{* * *}\right.$ & $-0.055^{* * *}$ \\
& $-0.027^{* * *}$ & $-0.029^{* * *}$ & $-0.027^{* * *}$ \\
Year 2003 & $(0.004)$ & $(0.005)$ & $(0.006)$ \\
& $-2.684^{* * *}$ & $-3.187^{* *}$ & $-2.497^{*}$ \\
Year 2004 & $(0.946)$ & $(1.333)$ & $(1.378)$ \\
& $-2.553^{* *}$ & $-4.547^{* * *}$ & -1.001 \\
Year 2005 & $(1.061)$ & $(1.523)$ & $(1.566)$ \\
& -0.381 & 2.070 & -2.127 \\
SSE $\times$ Year 2003 & $(1.218)$ & $(1.921)$ & $(1.696)$ \\
& $0.021^{* * *}$ & $0.023^{* * *}$ & $0.019^{* * *}$ \\
SSE $\times$ Year 2004 & $(0.004)$ & $(0.006)$ & $(0.007)$ \\
& $0.020^{* * *}$ & $0.027^{* * *}$ & $0.014^{*}$ \\
SSE $\times$ Year 2005 & $(0.005)$ & $(0.007)$ & $(0.007)$ \\
& $0.012^{* *}$ & 0.004 & $0.018^{* *}$ \\
Observations & $(0.005)$ & $(0.008)$ & $(0.007)$ \\
\hline \hline
\end{tabular}

NOTE: Probit models are used for estimation of the propensity score. Values in the parentheses are standard errors. ${ }^{* * *},{ }^{* *}$ and ${ }^{*}$ indicate respectively $1 \%, 5 \%$ and $10 \%$ significance levels. The dependent variable is a binary variable equal to one if the student has at least one self-employed parent. 
Table A2: Propensity Score Matching Estimates:

The Effect Self-Employed Parents on College GPA

\begin{tabular}{lccc}
\hline & All & Men & Women \\
& $(1)$ & $(2)$ & $(3)$ \\
\cline { 2 - 4 } OLS estimates & $-0.164^{* * *}$ & $-0.155^{* * *}$ & $-0.164^{* * *}$ \\
& $(0.034)$ & $(0.048)$ & $(0.050)$ \\
& {$[\mathrm{n}=1,122]$} & {$[\mathrm{n}=573]$} & {$[\mathrm{n}=549]$} \\
& & & \\
Nearest neighbor & $-0.113^{* *}$ & -0.089 & $-0.176^{* *}$ \\
(caliper=0.1) & $(0.054)$ & $(0.080)$ & $(0.084)$ \\
& & & \\
Nearest neighbor & $-0.113^{* *}$ & -0.098 & $-0.177^{* * *}$ \\
(caliper=0.05) & $(0.055)$ & $(0.077)$ & $(0.080)$ \\
& & & \\
Nearest neighbor & $-0.164^{* * *}$ & $-0.150^{* * *}$ & $-0.183^{* * *}$ \\
(radius=0.1) & $(0.035)$ & $(0.052)$ & $(0.054)$ \\
& & & \\
Nearest neighbor & $-0.157^{* * *}$ & $-0.149^{* * *}$ & $-0.183^{* * *}$ \\
(radius=0.05) & $(0.038)$ & $(0.053)$ & $(0.055)$ \\
& & & \\
Gaussian kernel & $-0.164^{* * *}$ & $-0.150^{* * *}$ & $-0.168^{* * *}$ \\
(bandwidth=0.1) & $(0.036)$ & $(0.046)$ & $(0.050)$ \\
& & & \\
Gaussian kernel & $-0.148^{* * *}$ & $-0.139^{* * *}$ & $-0.145^{* * *}$ \\
(bandwidth=0.05) & $(0.036)$ & $(0.051)$ & $(0.053)$ \\
& & & \\
Epanechnikov kernel & $-0.146^{* * *}$ & $-0.138^{* * *}$ & $-0.144^{* * *}$ \\
(bandwidth=0.1) & $(0.037)$ & $(0.051)$ & $(0.055)$ \\
$\begin{array}{l}\text { Epanechnikov kernel } \\
\text { (bandwidth=0.05) }\end{array}$ & $-0.143^{* * *}$ & $-0.139^{* * *}$ & $-0.137^{* * *}$ \\
\hline & $(0.038)$ & $(0.052)$ & $(0.056)$ \\
\hline
\end{tabular}

NOTE: There are 605 observations in comparison group and 517 in the treatment group for the pooled sample, and there are 304 (301) observations in the comparison group and 269 (248) observations in the treatment group for men (women). We use the bootstrap method to derive standard errors for the PSM estimators. Bootstrap standard errors based on 1,000 replications appear in parentheses below each estimate. ${ }^{* * *},{ }^{* *}$ and ${ }^{*}$ indicate respectively $1 \%, 5 \%$ and $10 \%$ significance levels. The variables included in the propensity score estimation are age, mother's education, father's education, SSE score, year of entrance, and SSE score and year of entrance interactions. The NN (random draw) estimator implements matching with replacement. 
Figure 1: Distribution of Estimated Propensity Scores
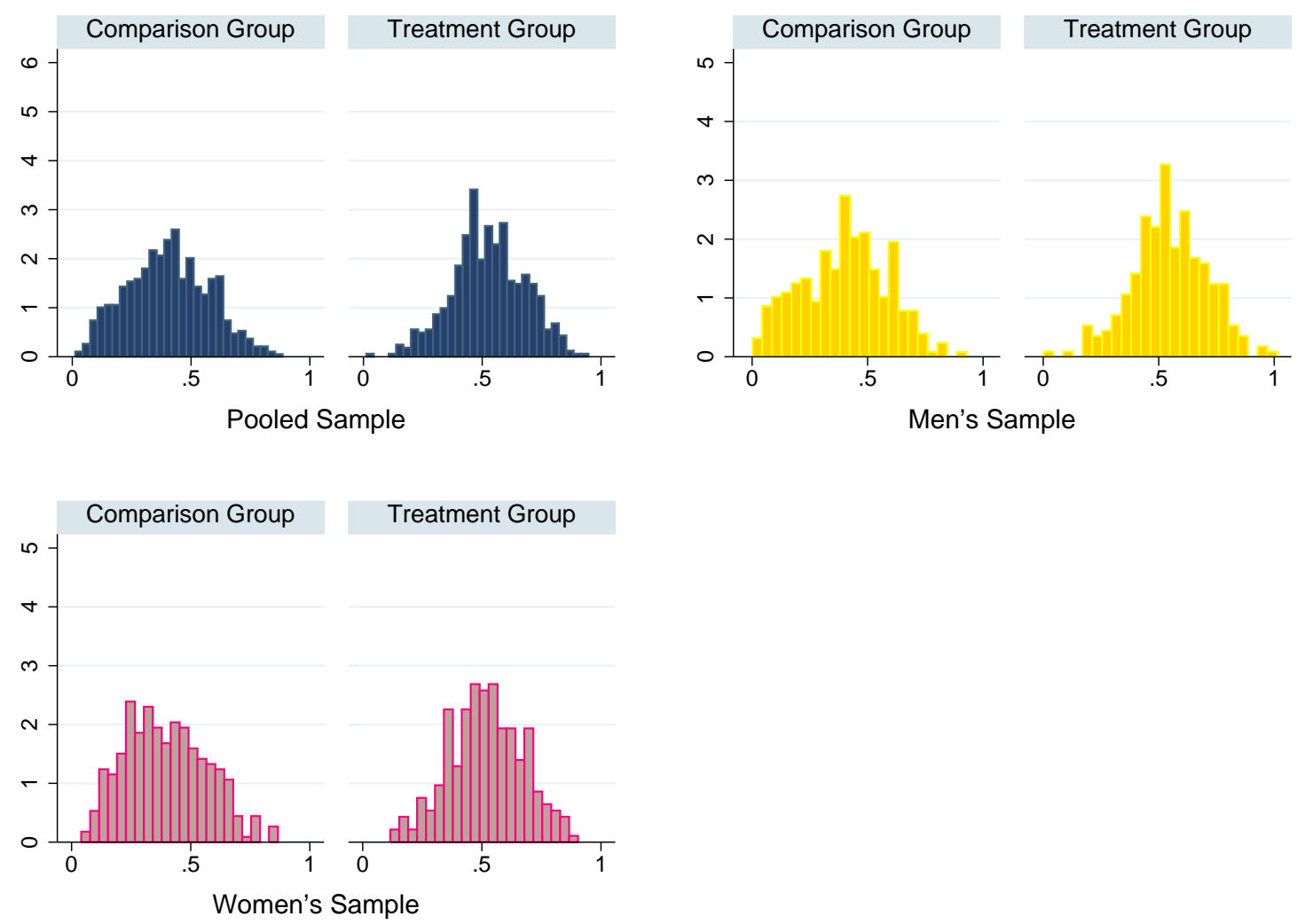


\section{Appendix B:}

Table B1: The Effect of Self-Employed Parents on the Number of Hours Studied

\begin{tabular}{|c|c|c|c|c|c|c|}
\hline & \multicolumn{6}{|c|}{ Number of Hours Studied } \\
\hline & \multicolumn{3}{|c|}{ Basic Specification } & \multicolumn{3}{|c|}{ Extended Specification } \\
\hline & $\begin{array}{l}\text { All } \\
(1) \\
\end{array}$ & $\begin{array}{c}\text { Men } \\
(2) \\
\end{array}$ & $\begin{array}{c}\text { Women } \\
(3)\end{array}$ & $\begin{array}{l}\text { All } \\
(4)\end{array}$ & $\begin{array}{c}\text { Men } \\
(5)\end{array}$ & $\begin{array}{c}\text { Women } \\
(6)\end{array}$ \\
\hline Control group mean & $\begin{array}{c}1.783 \\
{[1.090]}\end{array}$ & $\begin{array}{c}1.621 \\
{[0.983]}\end{array}$ & $\begin{array}{c}1.893 \\
{[1.146]}\end{array}$ & $\begin{array}{c}1.783 \\
{[1.090]}\end{array}$ & $\begin{array}{c}1.621 \\
{[0.983]}\end{array}$ & $\begin{array}{c}1.893 \\
{[1.146]}\end{array}$ \\
\hline $\mathrm{SE}_{\text {father only }}$ & $\begin{array}{c}0.050 \\
(0.117)\end{array}$ & $\begin{array}{c}0.213 \\
(0.175)\end{array}$ & $\begin{array}{l}-0.037 \\
(0.162)\end{array}$ & $\begin{array}{c}0.087 \\
(0.123)\end{array}$ & $\begin{array}{c}0.152 \\
(0.172)\end{array}$ & $\begin{array}{l}-0.034 \\
(0.185)\end{array}$ \\
\hline $\mathrm{SE}_{\text {mother only }}$ & $\begin{array}{l}-0.098 \\
(0.417)\end{array}$ & $\begin{array}{c}-0.682^{* * *} \\
(0.168)\end{array}$ & $\begin{array}{l}-0.067 \\
(0.494)\end{array}$ & $\begin{array}{c}0.007 \\
(0.473)\end{array}$ & $\begin{array}{c}-1.032^{* * *} \\
(0.314)\end{array}$ & $\begin{array}{c}0.229 \\
(0.513)\end{array}$ \\
\hline $\mathrm{SE}_{\text {both parents }}$ & $\begin{array}{c}0.015 \\
(0.187)\end{array}$ & $\begin{array}{c}0.265 \\
(0.313)\end{array}$ & $\begin{array}{l}-0.250 \\
(0.195)\end{array}$ & $\begin{array}{c}0.068 \\
(0.200)\end{array}$ & $\begin{array}{c}0.292 \\
(0.340)\end{array}$ & $\begin{array}{l}-0.259 \\
(0.246)\end{array}$ \\
\hline Age & $\begin{array}{c}0.118^{* * *} \\
(0.036)\end{array}$ & $\begin{array}{l}0.083^{*} \\
(0.043)\end{array}$ & $\begin{array}{c}0.147^{* * *} \\
(0.052)\end{array}$ & $\begin{array}{c}0.136^{* * *} \\
(0.046)\end{array}$ & $\begin{array}{c}0.043 \\
(0.061)\end{array}$ & $\begin{array}{c}0.168^{* * *} \\
(0.062)\end{array}$ \\
\hline Income/1,000 & $\begin{array}{c}0.0004 \\
(0.0012)\end{array}$ & $\begin{array}{c}0.001 \\
(0.001)\end{array}$ & $\begin{array}{c}-0.0006 \\
(0.001)\end{array}$ & $\begin{array}{l}0.0007 \\
(0.001)\end{array}$ & $\begin{array}{c}0.002 \\
(0.002)\end{array}$ & $\begin{array}{c}-0.0001 \\
(0.001)\end{array}$ \\
\hline Additional Controls $\dagger$ & & & & & & \\
\hline Exam Year Indicators & No & No & No & Yes & Yes & Yes \\
\hline Exam Score $\times$ Year & No & No & No & Yes & Yes & Yes \\
\hline College Major & No & No & No & Yes & Yes & Yes \\
\hline Parental Education & No & No & No & Yes & Yes & Yes \\
\hline F-stat [p-value] & $\begin{array}{c}0.11 \\
{[0.953]}\end{array}$ & $\begin{array}{c}12.21 \\
{[<.001]}\end{array}$ & $\begin{array}{c}0.55 \\
{[0.651]}\end{array}$ & $\begin{array}{c}0.18 \\
{[0.909]}\end{array}$ & $\begin{array}{c}5.62 \\
{[.001]}\end{array}$ & $\begin{array}{c}0.46 \\
{[0.709]}\end{array}$ \\
\hline Observations & 413 & 174 & 239 & 413 & 174 & 239 \\
\hline$R^{2}$ & 0.035 & 0.042 & 0.058 & 0.095 & 0.183 & 0.120 \\
\hline
\end{tabular}

NOTE: The dependent variable is the number of hours studied. Standard deviations and standard errors are given in brackets and parentheses respectively. The linearized standard errors are derived from a consistent variance-covariance matrix using Huber-White sandwich estimators. ${ }^{* * *},{ }^{* *}$ and ${ }^{*}$ indicate respectively $1 \%, 5 \%$ and $10 \%$ significance levels. The indicator variables for the Business Administration Economics Combined Honors major and test year 2002 are omitted.

†See next page for the parameter estimates of these variables. 
Table B1 (continued)

The Effect of Self-Employed Parents on the Number of Hours Studied

\begin{tabular}{|c|c|c|c|}
\hline & \multicolumn{3}{|c|}{$\begin{array}{l}\text { Number of Hours Studied } \\
\text { Extended Specification }\end{array}$} \\
\hline & $\begin{array}{l}\text { All } \\
(1)\end{array}$ & $\begin{array}{c}\text { Men } \\
(2)\end{array}$ & $\begin{array}{c}\text { Women } \\
(3)\end{array}$ \\
\hline Business Administration \& Economics & $\begin{array}{l}-0.377 \\
(0.378)\end{array}$ & $\begin{array}{l}-0.437 \\
(0.406)\end{array}$ & $\begin{array}{r}-0.470 \\
(0.655)\end{array}$ \\
\hline Economics & $\begin{array}{l}-0.156 \\
(0.385)\end{array}$ & $\begin{array}{l}-0.029 \\
(0.380)\end{array}$ & $\begin{array}{l}-0.346 \\
(0.681)\end{array}$ \\
\hline Government & $\begin{array}{l}0.284 \\
(0.450)\end{array}$ & $\begin{array}{l}0.838^{*} \\
(0.502)\end{array}$ & $\begin{array}{l}-0.154 \\
(0.752)\end{array}$ \\
\hline Economics (Honors) & $\begin{array}{l}-0.284 \\
(0.394)\end{array}$ & $\begin{array}{l}-0.391 \\
(0.432)\end{array}$ & $\begin{array}{c}0.091 \\
(0.666)\end{array}$ \\
\hline International Finance & $\begin{array}{l}-0.413 \\
(0.398)\end{array}$ & $\begin{array}{l}-0.376 \\
(0.464)\end{array}$ & $\begin{array}{l}-0.497 \\
(0.675)\end{array}$ \\
\hline International Relations & $\begin{array}{l}-0.188 \\
(0.389)\end{array}$ & $\begin{array}{l}-0.316 \\
(0.418)\end{array}$ & $\begin{array}{l}-0.176 \\
(0.667)\end{array}$ \\
\hline Business Administration & $\begin{array}{l}-0.316 \\
(0.373)\end{array}$ & $\begin{array}{l}-0.500 \\
(0.382)\end{array}$ & $\begin{array}{r}-0.320 \\
(0.661)\end{array}$ \\
\hline SSE Year 2003 & $\begin{array}{c}3.986^{* * *} \\
(1.527)\end{array}$ & $\begin{array}{l}2.487 \\
(2.34)\end{array}$ & $\begin{array}{l}5.233^{* *} \\
(2.176)\end{array}$ \\
\hline SSE Year 2004 & $\begin{array}{l}3.242^{* *} \\
(1.560)\end{array}$ & $\begin{array}{l}1.207 \\
(2.635)\end{array}$ & $\begin{array}{l}4.527^{* *} \\
(2.176)\end{array}$ \\
\hline SSE Year 2005 & $\begin{array}{c}0.693 \\
(1.429)\end{array}$ & $\begin{array}{l}-.467 \\
(2.196)\end{array}$ & $\begin{array}{l}1.070 \\
(1.975)\end{array}$ \\
\hline SSE Score & $\begin{array}{l}0.011^{*} \\
(0.006)\end{array}$ & $\begin{array}{l}0.003 \\
(0.010)\end{array}$ & $\begin{array}{l}0.017^{*} \\
(0.009)\end{array}$ \\
\hline SSE Score $\times$ Year 2003 & $\begin{array}{c}-0.018^{* *} \\
(0.007)\end{array}$ & $\begin{array}{l}-0.009 \\
(0.012)\end{array}$ & $\begin{array}{c}-0.024^{* *} \\
(0.010)\end{array}$ \\
\hline SSE Score $\times$ Year 2004 & $\begin{array}{c}-0.016^{* *} \\
(0.007)\end{array}$ & $\begin{array}{l}-0.006 \\
(0.012)\end{array}$ & $\begin{array}{r}-0.022^{*} \\
(0.010)\end{array}$ \\
\hline SSE Score $\times$ Year 2005 & $\begin{array}{l}-0.006 \\
(0.007)\end{array}$ & $\begin{array}{c}-0.0003 \\
(0.011)\end{array}$ & $\begin{array}{l}-0.010 \\
(0.010)\end{array}$ \\
\hline Father's Education & $\begin{array}{c}0.007 \\
(0.014)\end{array}$ & $\begin{array}{l}0.010 \\
(0.018)\end{array}$ & $\begin{array}{c}-0.003 \\
(0.020)\end{array}$ \\
\hline Mother's Education & $\begin{array}{c}0.011 \\
(0.013)\end{array}$ & $\begin{array}{c}0.021 \\
(0.019)\end{array}$ & $\begin{array}{l}-0.005 \\
(0.018)\end{array}$ \\
\hline
\end{tabular}




\section{Appendix C:}

\section{Dear Friends,}

We ask you to participate in our survey that is designed to understand the student profile. We want to investigate the determinants of academic achievement of college students of one of the best universities in Turkey. Please answer the questions correctly and as accurately as possible. The survey will take 5 minutes and your correct and full responses will help us to understand some student characteristics. No information provided by you will be seen by third parties except the two main researchers and submitted information will not be reported in a way that third parties can identify individuals. After matching the student data with the academic records, the names will be erased.

1. First and last name:

2. School number:
3. Age: a) 17
b) 18
c) $19 \quad$ d) 20
e) 21
f) 22
g) 23
h) $24+$

4. Gender:
a) MALE
b) FEMALE

5. Please write number of siblings you have: I have ...Male; .Female siblings.

6. Please write the ages of your BROTHERS (if it applies to you) $\ldots \ldots ; \ldots ; \ldots, \ldots ; \ldots ; \ldots ; \ldots, \ldots ; \ldots ; \ldots ; \ldots ; \ldots . \ldots ; \ldots ; \ldots .$.

7. Please write the ages of your SISTERS (if it applies to you) $\ldots ; \ldots \ldots ; \ldots ; \ldots ; \ldots ; \ldots ; \ldots ; \ldots ; \ldots ; \ldots ; \ldots ; \ldots ; \ldots \ldots$

8. Does your family have any kind of business?

a) YES

b) $\mathrm{NO}$

9. Did you go to the English Preparation class in University?

$\begin{array}{lll}\text { a) YES } & \text { b) NO }\end{array}$

10. Not counting the English Preparation year, Fall 2006 is your......semester (please circle the correct semester). a) 1 st

b) 2nd

c) $3 \mathrm{rd}$

d) 4 th

e) 5 th $\quad$ f) 6 th

g) 7 th

h) $8+$

11. After graduating from college, I plan to:
a) Work in the family business.
b) Start a new business.
c) Work as an employee.
d) Work as an employee to gain experience first and then work in the family business.
e) Work as an employee to gain experience first and then start a new business.
f) Go to graduate school.
g) Other. 
Consider your answer to the previous question and please write your post-graduation plans if you were asked these questions in the semester/time period below (Example: Ayse was planning to work in the family business during her first year but she changed her plans in her second year and in the third year with going to graduate school. In this case she would answer this question as follows:

$$
\left.1^{\text {st }} \text { Year } \underline{\mathrm{a}} \quad 2^{\text {nd }} Y e a r \underline{\mathrm{f}} \quad 3^{\text {rd }} \text { Year } \underline{\mathrm{f}}\right)
$$

Please leave it blank for the semesters you were not enrolled.

\begin{tabular}{|c|c|c|}
\hline $\mathbf{1 2 .}$ & $\mathbf{1 3 .}$ & $\mathbf{1 4 .}$ \\
\hline $1^{\text {st }}$ Year & $2^{\text {nd }}$ Year & $3^{\text {rd }}$ Year \\
\hline a) & a) & a) \\
b) & b) & b) \\
c) & c) & c) \\
d) & d) & d) \\
e) & e) & e) \\
f) & f) & f) \\
g) & g) & g) \\
\hline
\end{tabular}

15. If you have a family business, please write the total number of people (including those holding managerial posts) working in this business:

16. If you have a family business, please write the TOTAL number of people from the family who are working in the business:.............

17. If you have a family business, please write the number of people involved in it at managerial positions who are NOT from the family:

18. If you have a family business, please write the number of people who ARE from the family and who work in managerial positions:

19. Did you succeed in your first try at the University Entrance Exam (SSE)?
a) YES
b) $\mathrm{NO}$

20. What is your current GPA (as of the end of the last semester?)

21. What was your English proficiency when you completed high school?
a) Beginner.
b) Intermediate.
c) Advanced.

22. What was your university entrance exam score corresponding to the area (EQUALWEIGHT2)? 
23. Please fill in the circle corresponding to your major.

International Relations

International Finance

Government

Economics (Honors)

Economics

$\bigcirc$ Business Admin. and Economics

Business Administration

Business Admin. and Economics (Honors)

Academic year fellowship/scholarship: Please circle the one fits you for each time period.

\begin{tabular}{|l|c|c|c|c|}
\hline Question Number $\rightarrow$ & $\mathbf{2 4 .}$ & $\mathbf{2 5 .}$ & $\mathbf{2 6 .}$ & $\mathbf{2 7 .}$ \\
\hline & $2006 / 2007$ & $2005 / 2006$ & $2004 / 2005$ & $2003 / 2004$ \\
\hline a) No fellowships/scholarships. & a) & a) & a) & a) \\
b) Turkish Edu. Ministry & b) & b) & b) & b) \\
c) University Merit F. & c) & c) & c) & c) \\
d) University Sports, Art F. & d) & d) & d) & d) \\
e) Other Fellowships. & e) & e) & e) & e) \\
\hline
\end{tabular}

28. Pick the type of high school you graduated from:
a) Private (English as a 2nd Lang.)
f) Public Anatolian (English as a 2nd Lang.)
b) Private (Other Lang.)
g) Public Anatolian.(Other Lang.)
c) Private Science.
h) Public Science.
d) Private Other.
i) Public Super.
e) Regular Public (Straight.)
j) Public Other.

29. Please rank the statement below from 1 to 5 (eg. $1=\mathrm{I}$ totally disagree, $5=$ totally agree.)

- I take notes in classes:.

- If you have a family business: I believe that my education will help me in the family business:

- If you are planning to start a new business: I believe that my education will help me in my future business:

30. On average how many hours a day do you study?

31. On average how many hours a day do you sleep?.....

32. Which group does your yearly family income fall into?
a) 0-20 thousand YTL
b) 20-40 thousand YTL
c) 40-60 thousand YTL
d) 60-80 thousand YTL
e) 80-100 thousand YTL
f) 100-120 thousand YTL
g) 120-140 thousand YTL
h) 140-160 thousand YTL
i) $160+$ thousand YTL 
Please choose the education level of your;

\begin{tabular}{|l|c|c|}
\hline Question Number $\rightarrow$ & 33. & $\mathbf{3 4 .}$ \\
\hline & MOTHER & FATHER \\
\hline a) Grade school graduate/No formal Education. & a) & a) \\
b) Middle school graduate. & b) & b) \\
c) High school graduate. & c) & c) \\
d) University graduate. & d) & d) \\
e) Graduate school diploma. & e) & e) \\
\hline
\end{tabular}

Please choose the occupation of your...;

\begin{tabular}{|l|c|c|}
\hline Question Number $\rightarrow$ & 35. & 36. \\
\hline & MOTHER & FATHER \\
\hline a) Housewife or Does not work. & a) & a) \\
b) Retired. & b) & b) \\
c) Wage earner, Works as an employee. & c) & c) \\
d) Self-Employed/Business owner/Employer. & d) & d) \\
e) Other Group/Professional & e) & e) \\
(Lawyer, Doctor, Auditor, Pharmacist etc.) & & \\
\hline
\end{tabular}

37. Please circle the option that applies to you. My parents are:
a) Divorced.
b) Separated.
c) Together.
d) Other.

38. Who do you live with?
a) Both of my parents.
b) With my mother.
c) With my father.
d) My parents live out of Istanbul, I live in an apartment/dorm.
e) My parents live in Istanbul, but I live in a separate apartment/dorm.
f) Other 